\title{
The persistence of subsistence: qualitative social-ecological modeling of indigenous aquatic hunting and gathering in tropical Australia
}

\author{
Marcus Barber $^{1}$, Sue Jackson ${ }^{2}$, Jeffrey Dambacher ${ }^{3}$ and Marcus Finn $^{4}$
}

\begin{abstract}
Subsistence remains critical to indigenous people in settler-colonial states such as Australia, providing key foundations for indigenous identities and for wider state recognition. However, the drivers of contemporary subsistence are rarely fully articulated and analyzed in terms of likely changing conditions. Our interdisciplinary team combined past research experience gained from multiple sites with published literature to create two generalized qualitative models of the socio-cultural and environmental influences on indigenous aquatic subsistence in northern Australia. One model focused on the longer term (inter-year to generational) persistence of subsistence at the community scale, the other model on shorter term (day to season) drivers of effort by active individuals. The specification of driver definitions and relationships demonstrates the complexities of even generalized and materialist models of contemporary subsistence practices. The qualitative models were analyzed for emergent properties and for responses to plausible changes in key variables: access, habitat degradation, social security availability, and community dysfunction. Positive human community condition is shown to be critical to the long-term persistence of subsistence, but complex interactions of negative and positive drivers shape subsistence effort expended at the individual scale and within shorter time frames. Such models enable motivations, complexities, and the potential management and policy levers of significance to be identified, defined, causally related, and debated. The models can be used to augment future models of human-natural systems, be tested against case-specific field conditions and/or indigenous perspectives, and aid preliminary assessments of the effects on subsistence of changes in social and environmental conditions, including policy settings.
\end{abstract}

Key Words: Aboriginal people; future scenarios; natural resource management; qualitative modelling; subsistence fishing

\section{INTRODUCTION}

Fishing and hunting for subsistence ${ }^{1}$ continues to be an important activity for indigenous peoples in settler-colonial societies such as Australia. This importance derives not only from the physical sustenance it provides, but also from the role that subsistence activities can play in cultural identity and in creating and sustaining human connections with important places. Indigenous people emphasize subsistence as key to sustaining individual and collective identity, particularly in circumstances in which the retention of formal religious, kinship, and linguistic associations have been heavily affected by colonization processes. Processes of state recognition of indigeneity often incorporate subsistence as a key cultural attribute that requires formal documentation to receive limited forms of recognition and protection. The research literature also reflects this subsistence emphasis, containing rich and diverse accounts of its potential significance (Ingold et al. 1988, Ingold 2000, Gombay 2014), including accounts from indigenous Australia (Altman 1987, Bradley 1991, Povinelli 1992, Barber 2005, Bliege Bird and Bird 2008). The persistence of subsistence into the 21 st century appears to have multiple bases.

However, the persistence of subsistence is not normally analyzed through formal models of the key drivers and constraints, or through analyses of the effect of changes in key variables. Generating models of such systems can be useful in: highlighting the assumptions underlying statements about the ongoing significance and distinctiveness of indigenous subsistence; demonstrating how these key drivers and variables interact; revealing emergent properties in the modeled system; suggesting foci and pathways for future research; and enabling the potential effects of changing conditions to be examined.
Such researcher-driven analyses cannot and should not replace accounts generated by and with indigenous peoples based on their own perspectives, but they can play an important role in deepening contemporary understanding. Here, we draw on a range of expertise and information sources to answer the following questions: What are the key drivers and constraints that explain the ongoing persistence of individual and communal indigenous subsistence in northern Australian aquatic social-ecological systems? How is that persistence potentially affected by plausible alterations in key drivers?

In addressing these questions, we are responding to a range of research and policy conditions across international, national, and regional scales. Firstly, at a general level, modeling is an increasingly prevalent tool in bureaucratic decision-making processes, and so understanding how models may be generated and applied with respect to indigenous peoples (who are often the subject of such decisions) is an important issue (Barber and Jackson 2015). Secondly, there is a tendency in the conceptual modeling of aquatic environments to limit the representation of socioeconomic systems, especially human decision-making (Douglas et al. 2005, Jardine et al. 2012), and instead treat humans as a type of boundary condition without reciprocal links to floodplain dynamics, food webs, flow ecology, etc. (Di Baldassarre et al. 2013). Thirdly, with regard to general categorizations of hunting and fishing effort, the aquatic-focused indigenous activity we characterize is largely undertaken without significant interaction with commercial markets for the proceeds (Gorman et al. 2008), yet government policies and assessments clearly differentiate it from standard definitions of recreational activity (Henry and Lyle 2003).

${ }^{1}$ Land and Water Flagship, CSIRO, ${ }^{2}$ Australian Rivers Institute, Griffith University, ${ }^{3}$ Digital Productivity Flagship, CSIRO, ${ }^{4}$ Australian Fisheries Management Authority 
Despite this differentiation, the underlying drivers of indigenous effort in aquatic systems (and therefore their articulation with wider recreational and commercial drivers) remain underspecified. Also, the majority of international studies of indigenous subsistence focus on indigenous communities in developing countries without the social welfare safety nets that exist in Australia, which alter key dynamics (Rowcliffe et al. 2005, Rist et al. 2008, Parry et al. 2009). The extended history of studies of indigenous Australian hunter-gatherers provides an important enabler of the current study (Thomson 1949, Meehan 1982, Altman 1987, Povinelli 1992, Barber 2005, Bliege Bird and Bird 2008), but also highlights the need to conceptualize how the ongoing persistence of subsistence activity is situated within a wider suite of activities characteristic of contemporary indigenous lives (Altman 1987, Povinelli 1992, Rose 2000, Toussaint 2014).

Lastly, northern Australia is a region where indigenous people compose approximately one-quarter of the population (Carson et al. 2009) and hold title to one-third of the land mass (Altman et al. 2009), and where there is considerable potential for increased water and other natural resource development. A key issue for natural resource planning in such contexts is how the environmental, socioeconomic, policy, and legal changes associated with development (particularly water development) could potentially affect indigenous subsistence activity (Jackson and Altman 2009, Jackson et al. 2012a). Models that can represent the dynamic interactions between people and the environment will assist in meeting this need for integrated assessments (Stoeckl et al. 2013).

The models of indigenous subsistence presented here draw on diverse information sources and combine observations and insights from our research activities undertaken in a range of field contexts across northern Australia since the year 2000. For this reason, they are necessarily and intentionally generalized; rather than attempting to produce a definitive account of a particular case study, our modeling team identified general features of the underlying context for and drivers of contemporary indigenous subsistence behavior that had been observed consistently across time and space. The data sources underlying the models therefore include: our previous research that focused directly on subsistence; formal observations made and statements recorded during participatory research focused on broader questions of indigenous natural resource rights and natural resource management; informal observations made during other periods spent living and working in indigenous communities; and the research literature about indigenous Australian subsistence. Further details about the information sources and assumptions underpinning the models are provided below, but the diverse nature of this information was a key determinant of the choice of modeling approach.

The modeling approach selected for this work is based on a qualitative description and analysis of complex social and ecological systems in which variables, relationships, and processes are well known but difficult to measure (Puccia and Levins 1985). This qualitative modeling approach has been adopted previously to assess multiple factors affecting subsistence activity in a crosscultural context (Dambacher et al. 2007). The current case is also cross-cultural, but additionally involves a minority indigenous population surrounded by a dominant colonial society. This modeling exercise aimed to describe the environmental and cultural processes that drive and regulate systems of aquatic subsistence, understand the general dynamics of these systems, and predict how the systems might respond to potential perturbation or intervention scenarios.

We next describe: the methods undertaken, qualitative modeling techniques, the expertise of the modeling participants, the data sets used, the adoption of a materialist perspective in specifying causal relations, and the iterative process of constructing models. We then present the results, including tables that specify details of models, descriptions of the models' emergent properties, and qualitative predictions of perturbation responses. Finally, we analyze the implications of the modeling exercise.

\section{METHODS}

\section{Qualitative modeling}

Qualitative methods for the analysis of complex systems have been developed in a diverse array of disciplines, including economics (Samuelson 1947, Quirk and Ruppert 1965, Hale et al. 1999), system dynamics (Coyle 2000), structural modeling (Roberts 1971), ecology (Levins 1974), and artificial intelligence (Kuipers 1994, Salles and Bredeweg 2006). Some emphasize a matrix approach, whereby the sign $(+,-, 0)$ of relationships between variables are detailed in an interaction or Jacobian matrix, which is then analyzed algebraically for questions of sign solvability (Samuelson 1947, Quirk and Ruppert 1965, Hale et al. 1999). Another approach emphasizes a graphical analysis, whereby the topology of an interaction network is assessed to understand the causal influence of interaction pathways, branches, and feedback cycles to a system's dynamics (Roberts 1971, Levins 1974, Coyle 2000). Both of these approaches are based on the same mathematical foundations and can be seen to yield equivalent results (Puccia and Levins 1985, Dambacher et al. 2002, 2003b). A third approach is based on qualitative simulations of a set of ordinary differential equations. This technique relies on the mapping of transitions between critical thresholds in the functional relationships between variables, which is then used to predict the possible dynamics and states of a system (Kuipers 1994, Salles and Bredeweg 2006).

Here, we apply the technique of qualitative modeling (also called loop analysis or qualitative mathematical modeling; Levins 1974, Puccia and Levins 1985, Levins 1998, Dambacher et al. 2007) as a means to understand the general dynamics of socioeconomic and ecological systems when variables and rates of interactions between variables cannot be measured precisely or otherwise determined. Qualitative modeling proceeds through the construction and analysis of signed directed graphs, or signed digraphs. System variables (graph nodes) are connected by links (graph vertices) that represent the sign $(+,-, 0)$ of a variable's action or effect that directly increases or decreases the relative level or amount of another variable. Links that represent a positive effect end in an arrow, whereas those that represent a negative effect end in a small circle. Links that directly connect a variable to itself are termed self-effects. A negative self-effect suggests self-regulation such that in the absence of the influence of other variables in the modeled system, the variable tends to settle on a familiar, or equilibrium, level. Based on the structure 
of a signed digraph model, an analysis of its feedback properties provides insight into a system's expected behavior and dynamics, both in terms of its potential for stability and in predictions of how it can respond to a sustained change or perturbation.

Qualitative stability is based on the well-known Routh-Hurwitz criteria, which require that (1) the system is not dominated by positive feedback, and (2) there is a balance between feedback cycles of short and long length (Dambacher et al. 2003b). Analysis of model stability thus involves identification of the positive and negative feedback cycles that arise from the entire network of interactions. From this, one may describe the feedbacks that drive and regulate the whole system, and under what conditions a system will or will not be stable. Feedback cycles of length equal to one are simply self-effects, whereas those of longer length can involve the product of pairwise links between variables in reciprocal relationships (i.e., of length equal to two) or any number of conjunct links between variables that complete a cyclical path. For example, a simple predator-prey system has a negative feedback cycle of length two, which is a product of the positive and negative links shared between the predator and prey. Alternatively, competition between two variables creates a positive feedback cycle of length two that is potentially destabilizing. Here, the problem of stability reduces to an algebraic inequality that is readily interpretable; stability for this simple competition system requires relatively strong selfregulation such that the product of the two competitors' selfeffects are greater than the product of the pairwise competition links (Dambacher et al. 2003b).

While the question of model stability is concerned with whether a system can recover from a short-term shock to one of its variables, additionally, one can predict the direction of change (increase + , decrease - , no change 0 ) in variables due to a sustained input (e.g., intervention or perturbation) to the system (Puccia and Levins 1985, Dambacher et al. 2002). This analysis considers the sign of all of the direct and indirect pathways, or effects that lead from the input variable to the response variable. A response prediction that is composed of effects that are all of the same sign will have complete sign determinacy, but when there is a mixture of positive and negative effects, the response is ambiguous.

One approach to resolving ambiguous predictions is to consider the ratio or weight of the net number of positive and negative effects to the total number of effects, which formally defines a prediction weight (Dambacher et al. 2002). In calculating prediction weights, negative and positive effects cancel in calculation of the net number of effects (e.g., a ratio of three positive to one negative effect corresponds to a net of two positive effects; dividing this by the total of four effects gives a prediction weight of 0.5 for a positive response). A probabilistic interpretation of sign determinacy for qualitative response predictions has been developed through simulation studies using random parameter space allocated to an array of signed digraph models (Dambacher et al. 2003a, Hosack et al. 2008). For instance, a response prediction with a prediction weight of 0.5 has been generally found to have $>90 \%$ probability of sign determinacy. Here, we distinguish ambiguous response predictions with a relatively high degree of sign determinacy with a cut-off of $\geq 0.85 \%$.
By considering only the sign of interactions, qualitative models readily permit the depiction of variables from different types of systems (or disciplines) such that physical, biological, and ecological variables can be included alongside social, cultural, and economic variables. Building such models, however, requires consideration of whether the model variables and interactions are scaled commensurately to each other. The primary spatial scale considered here is that of a geographically discrete regional or remote Australian indigenous community, but influential nodes (e.g., income, distribution) must necessarily incorporate scales beyond the immediate geographical context. Thus, we modeled the system at both a relatively long (multiyear to one generation) time scale and a shorter day-to-season time scale associated with the subset of the community that most actively participates in subsistence hunting and gathering practices.

\section{Data sets and observations}

The modeling team included an anthropologist, a geographer, an aquatic ecologist, and a modeler, and as noted above, the syntheses were based on observations derived from a range of sources. Two key data sets (and the research processes undertaken to generate them) were particularly significant. One data set was a 12-month participatory resource use survey undertaken by one author in coastal Arnhem Land in the Northern Territory, which was augmented by additional observations made over a subsequent 6-month period (Barber 2004, 2005, 2010). The second data set was a multiyear survey of aquatic subsistence in indigenous communities in two major Australian river catchments, the Daly River in the Northern Territory and the Fitzroy River in Western Australia, undertaken by the Commonwealth Scientific and Industrial Research Organisation (CSIRO; Jackson et al. 2012a, 2014). This survey was supported by an additional two years of data collected by an indigenous organization from the Mitchell River in North Queensland (Scheepers and Jackson 2012, Jackson et al. 2014). These primary data sets were augmented by significant observations and experiences regarding indigenous subsistence derived from multiple applied ethnographic investigations of indigenous water values, rights, and interests as they relate to water development and water planning (Cooper and Jackson 2008, Barber and Jackson 2011 a,b,c, Maclean et al. 2012, Barber 2013) and to additional studies of knowledge associated with land and natural resource use (Barber 2011, Barber and Jackson 2012, Barber et al. 2014). In constructing the final qualitative models, observations derived from our research projects were augmented by sources in the published literature. In particular, these included: studies of indigenous subsistence (McCarthy and McArthur 1960, Meehan 1982, Altman 1987, Povinelli 1992, Bliege Bird and Bird 2008); literature on the wider social significance of riparian environments and aquatic resources to indigenous communities (Merlan 1982, 1987, Morphy 1984, Sullivan 1998, Strang 2001, 2005, Toussaint et al. 2005, Morphy and Morphy 2006, Toussaint 2014); and general references about indigenous social interactions with the landscape (Williams 1986, Rose 1996, 2000, Strang 1997, Bradley 2010). Synthesizing across geographical environments and across a variety of data sources required a level of expert inference and opinion, as well as a range of assumptions.

\section{Causal assumptions}

Although based on knowledge gained from working with indigenous communities, the qualitative models described here 
do not include direct input from indigenous resource users, nor were they validated with indigenous people. This was partly because of decisions about what kind of causation would be included, but also because they were intended primarily as general, rather than case-study specific representations. However, the ethnographic, subsistence, and seasonal research conducted over the previous 15 years that informed these qualitative expertdriven models was collected with the consent and active participation of indigenous individuals and groups.

Consistent with the decision regarding indigenous validation, the qualitative model reflects a materialist perspective common to Western scientific frameworks, rather than attempting to represent complete indigenous understandings of all the factors affecting or driving subsistence activity. These two perspectives overlap considerably, but there are some important differences, notably with respect to the role played by spirits, creators, and other metaphysical powers in the landscape. Considerable research exists that emphasizes how hunter-gatherers understand themselves and their surroundings in sometimes quite different ways from perspectives characteristic of the materialist natural sciences (Rose 1996, 2000, Strang 1997, Ingold 2000, Bradley 2010). In the qualitative models represented here, metaphysical powers are considered only in terms of the effect the belief in their existence has on human behavior, rather than such powers being included as causal agents in and of themselves (an inclusion that would be consistent with indigenous perspectives).

\section{Qualitative model development}

The development of qualitative models followed a three-step process conducted between 2011 and 2013. First, participants identified the problem to be addressed, the scope of the analysis, and the appropriate modeling approach to adopt. Second, a threeday workshop of semi-structured discussions iteratively developed draft generic qualitative models of indigenous subsistence systems. Third, refinement and revision of draft models and further investigation of the literature was undertaken during the writing and review process for this paper. This iterative process enabled the meaningfulness of assumptions to be critically reviewed, the appropriateness of nodes and links to be debated and refined, additional information and supporting literature to be sought, and modifications to be made based on further thought, additional evidence, and critical review.

The modeling process focused on developing two qualitative models of catch and effort. The first, model A, emphasized the broad positive drivers and dynamics of community-level subsistence that support the long-term persistence of the activity across time scales from one year to one generation. The second, model $\mathrm{B}$, focused on the circumstances and motivations of catch and effort by high-activity individuals on the shorter time frame of one day to one season. The two qualitative models and the node and link definitions that underpin them are presented in Results.

\section{Perturbation and intervention}

Following preliminary system analysis, the possible response of the modeled system to scenarios involving potential perturbations and interventions was examined. Model B was prioritized in this process, both because drivers at this scale underlay the longer term patterns depicted in model $\mathrm{A}$, and because the more complex relationships depicted in model B provided a greater basis for examining multiple effects of the altered state of key drivers. Four separate perturbation scenarios were developed that consider: (1) an increase in community dysfunction (scenario B4), (2) degradation of floodplain habitat (scenario B24), (3) a decrease in social security payments (scenario B9), and (4) an increase in access (scenario B13). The plausibility of these scenarios are analyzed further in the Discussion.

\section{RESULTS}

\section{Model A: long-term aquatic subsistence effort at the community} scale

Model A represents the community-scale determinants of the persistence of indigenous subsistence activity through time, emphasizing positive interactions between compound nodes (Tables 1 and 2). The individual nodes and links are described in Tables 1 and 2, but some preliminary comments about node identification and key assumptions are warranted.

1. A complex compound index called community well-being (A4) is used to describe individual and collective physical and mental health. Well-being is a favored term in a range of contexts, including indigenous contexts, because of its wider connotations beyond biomedical measures or determinants of physical health (Burgess et al. 2009).

2. It is assumed that hunting effort (A5) has a positive effect on well-being (A4), regardless of the outcome. This reflects commonly heard indigenous understandings of how being out "on country" makes people "feel good" (Povinelli 1992, Rose 1996, Barber 2005, Bradley 2010) and that a level of physical exertion may be involved (Burgess et al. 2009). Although this assumption appears robust where welfare dependence, substance abuse, and inactivity are significant issues, the effect of subsistence effort may be more ambiguous (e.g., school absences, missed medical appointments, poorly attended community meetings). The question of whether a specific instance of effort is individually or collectively beneficial is a matter of judgement and circumstance, but here the collective effect is assumed to be positive.

3. It is assumed that hunting and fishing does not have a significant ecological effect in terms of depleting the population of food resources (A1) in such a way that catch or any other biophysical variable is affected. Localized pressure on finite large-bodied target species may be evident (Close et al. 2014), but North Australian tropical river systems have high river health ratings (Pusey 2011b), few dams and other regulatory structures, and large seasonal flood cycles. These all facilitate connectivity and migration, which permits repopulation of floodplain and channel habitats, mitigating the local effect of indigenous subsistence activities.

4. Available time is not a constraint on the level of effort. This assumes that, averaged across longer time frames at the community level, there is sufficient available "free time" to sustain subsistence activity commensurate with the state of other drivers of effort. This assumption is based on the relatively low levels of formal employment and correspondingly relatively high levels of unallocated time available across contemporary indigenous communities. 
Table 1. Definition of nodes in model A.

\begin{tabular}{|c|c|c|}
\hline Node & Node title & Explanation and supporting literature \\
\hline 1 & Food resources & $\begin{array}{l}\text { Edible fauna and flora targeted by indigenous hunters and fishers (Meehan 1982, Altman 1987, Povinelli } \\
\text { 1992, Walsh 2008, Pusey 2011 b, Jackson et al. 2012a). Seasonality (Baker 1999, Clarke 2009, Prober et al. } \\
\text { 2011, Woodward et al. 2012) and nutritional preferences (Rae et al. 1982, O’Dea et al. 1991, Miller et al. } \\
\text { 1993, Rouja et al. 2003) are both relevant to prioritizing food resource selection. }\end{array}$ \\
\hline 2 & Catch & $\begin{array}{l}\text { The results of successful effort, i.e., the food resources caught/gathered/taken by fishers, hunters, and } \\
\text { gatherers (Altman 1987, Povinelli 1992, Barber 2004, Jackson et al. 2012a). }\end{array}$ \\
\hline 3 & Distribution of catch & $\begin{array}{l}\text { Incorporates personal consumption and sharing with kin and/or co-residents, including symbolic sharing } \\
\text { associated with ritual events and prohibitions (Altman 1987, Peterson 1993, Barber 2005). }\end{array}$ \\
\hline 4 & Community well-being & $\begin{array}{l}\text { Compound term encompassing mental, physical, social, and cultural health (Zubrick et al. 2004, Carson et } \\
\text { al. 2007, Dockery 2010, Biddle and Swee 2012). }\end{array}$ \\
\hline 5 & Effort & $\begin{array}{l}\text { Motivation, time, energy, and resources expended by the residential population to obtain food resources } \\
\text { (McCarthy and McArthur 1960, Meehan 1982, Altman 1987, Walsh 2008, Codding et al. 2011). Sufficient } \\
\text { habitat and available technology are assumed. }\end{array}$ \\
\hline 6 & Income & $\begin{array}{l}\text { Incorporates time-consuming income-generating activity as well as time-independent income such as } \\
\text { welfare and industry royalty payments (Daly and Hawke 1993). These are depicted as having similar } \\
\text { functional effects: negative for effort, by enabling commercial food purchases (Smith and Smith 1999, } \\
\text { Saethre 2005, Scelza et al. 2014); and/or positive for access, by enabling the purchasing and maintenance of } \\
\text { technology. Unpaid work (such as ceremonial activity) may have complex effects on access and effort but } \\
\text { are not incorporated in this node (see node 10). }\end{array}$ \\
\hline 7 & Access & $\begin{array}{l}\text { Access is shaped by a range of variables. A key variable is the availability of technology (cars, boats, guns, } \\
\text { fishing gear) that increases range and hunting effectiveness (Altman 1983, Altman 1987, Barber 2004, } \\
\text { Altman and Hinkson 2007, Walker 2010). The potential positive effect on motivation (effort) of these items } \\
\text { is counteracted by the time expended in making money to purchase them, so no direct link to effort is } \\
\text { included in this model. Physical constraints on access can include seasonal environmental barriers such as } \\
\text { flooded rivers (Barber 2005) or high daytime temperatures (Ulijaszek 2001). Cultural restrictions can limit } \\
\text { access (Biernoff 1978, Morphy 2004), and institutional arrangements such as the recognition of land tenure } \\
\text { can also facilitate or hinder access (Williams 1986, Strang 1997, Holmes 2010, Barber and Jackson 2011a, } \\
\text { Barber 2013). }\end{array}$ \\
\hline 8 & Healthy country & $\begin{array}{l}\text { Perceptions of the state of indigenous estates, or "country", which are directly affected by the state of } \\
\text { natural habitats (Pusey 2011a,b), the general well-being of indigenous communities (Burgess et al. 2009, } \\
\text { Garnett et al. 2009, Biddle and Swee 2012), the appropriate conduct of those present on the country } \\
\text { (Biernoff 1978, Baker 1999, Putnis et al. 2007), and assessments of metaphysical (spiritual and ancestral) } \\
\text { health (Rose 1996, Strang 1997, Bradley 2001, 2010). }\end{array}$ \\
\hline 9 & Habitat & $\begin{array}{l}\text { Key areas/environments that generate food and other natural resources obtained during subsistence activity } \\
\text { (Keen 2003, Barber 2005, Pusey 2011b, Chase and Sutton 1981). }\end{array}$ \\
\hline 10 & Looking after country & $\begin{array}{l}\text { Human actions that materially affect the physical health of the landscape and/or alter human perceptions } \\
\text { of landscape health (Williams and Hunn 1982, Strang 1997, Baker et al. 2001, Johnston et al. 2007, } \\
\text { Morrison 2007, Walsh 2008, Laudine 2009, Altman and Kerins 2012; A. Griffiths, unpublished manuscript } \\
\text { presented at the Third International Wildlife Management Congress, University of Christchurch, } \\
\text { Christchurch, New Zealand). This incorporates: contemporary natural resource management activities } \\
\text { (Phelan 2003, Walker 2010, Stacey et al. 2013); customary activities with material effects such as burning } \\
\text { regimes and water diversions (Altman 1983, Rose 1995, Russell-Smith et al. 1997, Horstman and } \\
\text { Wightman 2001, Laudine 2009, Gammage 2011, Barber and Jackson 2012, 2014); and customary activities } \\
\text { that are influential on perceptions of health but without evident material effects such as conducting } \\
\text { ceremonies and communicating with ancestral powers (Biernoff 1978, Keen 1994, Morphy 1995, Rose } \\
\text { 2000). }\end{array}$ \\
\hline 11 & External support & $\begin{array}{l}\text { Support for natural resource management activities from agencies and institutions (Baker et al. 2001, } \\
\text { Garnett et al. 2009, Finn and Jackson 2011, Altman and Kerins 2012, Hill et al. 2013). }\end{array}$ \\
\hline
\end{tabular}

\section{Model B: drivers and constraints on aquatic subsistence effort by active indigenous hunters and fishers}

Model B represents the drivers and constraints acting on individual hunters and fishers with high levels of subsistence activity, and the dynamics of time and effort expended by them. This qualitative model makes similar assumptions to model A, but with some variations in how the assumptions are expressed (Tables 3 and 4). Subsistence activity is again presumed to have minimal ecological effect on the target species, but catch does affect a new node, motivation (B7). Subsistence effort (B2) is also assumed to be beneficial regardless of its success, but to identify more effectively an alternative pathway for subsistence motivation, a node called community dysfunction (B4) is introduced. In relatively healthy individuals with high levels of subsistence activity, it has been observed that community dysfunction can lead to a mental state (frustration, B5), and that one response to this frustration is to go hunting and fishing. The effort (B2) expended has a direct negative effect on both frustration and dysfunction (B4 and B5). However this element of model B is effectively capturing a short-term dynamic that is subsumed within the broader long-term dynamics of model A, which clearly indicate that the persistence of subsistence emerges 
Table 2. Definition and explanation of links in model A.

\begin{tabular}{|c|c|c|c|}
\hline $\begin{array}{l}\text { From } \\
\text { node }\end{array}$ & To node & $\begin{array}{c}\text { Direction of } \\
\text { effect }\end{array}$ & Explanation and supporting literature \\
\hline 1 & 2 & + & Catch is dependent on sufficient target resources being available \\
\hline 2 & 3 & + & Distribution requires successful catch \\
\hline 3 & 4 & + & Sharing reinforces social ties, influencing community well-being (Altman 1987, Peterson 1993, Barber 2005) \\
\hline 4 & 5 & + & $\begin{array}{l}\text { Well-being influences effort because healthy people are more active (Reid and Trompf 1991, Anderson 1996, } \\
\text { Carson et al. 2007, Johnston et al. 2007, Putnis et al. 2007) }\end{array}$ \\
\hline 4 & 10 & + & Well-being motivates people to manage their country effectively (Putnis et al. 2007, Burgess et al. 2009) \\
\hline 5 & 4 & + & $\begin{array}{l}\text { Effort influences well-being regardless of catch because the act of hunting and fishing can facilitate social and } \\
\text { intergenerational connections, attachments, and knowledge exchanges (Povinelli 1992, Barber 2005, Bradley } \\
\text { 2010) }\end{array}$ \\
\hline 5 & 2 & + & Effort expended influences catch (McCarthy and McArthur 1960, Altman 1987) \\
\hline 6 & 4 & + & Employment improves well-being (Anderson 1996, Zubrick et al. 2004) \\
\hline 6 & 5 & - & $\begin{array}{l}\text { Paid employment reduces time for subsistence hunting and enables the purchase of commercial food, thereby } \\
\text { reducing the direct need for subsistence provisioning effort (Altman 1987, Smith and Smith 1999, Scelza et al. } \\
\text { 2014); payments free of labor obligations (e.g., pensions or royalties) are functionally similar, reducing the need } \\
\text { for effort without requiring time }\end{array}$ \\
\hline 6 & 7 & + & $\begin{array}{l}\text { Employment (and labor-independent income) improves mobility and access by enabling the purchase of } \\
\text { technology such as cars and boats (Barber 2005, Fogarty 2005, Long and Memmott 2005) }\end{array}$ \\
\hline 7 & 2 & + & $\begin{array}{l}\text { Access influences catch by increasing the amount of habitat accessible, the target species options, and overall } \\
\text { hunting effectiveness (Povinelli 1992, Barber 2005) }\end{array}$ \\
\hline 8 & 4 & + & Well-being is improved by perceptions that country is healthy (Burgess et al. 2009) \\
\hline 9 & 1 & + & Habitat health and availability positively influences food resource availability \\
\hline 9 & 8 & + & $\begin{array}{l}\text { Habitat health and availability positively influences assessments of the overall condition of the country } \\
\text { (McGregor et al. 2010) }\end{array}$ \\
\hline 10 & 8 & + & $\begin{array}{l}\text { Activities that materially and/or metaphysically "look after the country" influence assessments of its condition } \\
\text { (Morrison 2007, Putnis et al. 2007, Ens and McDonald 2012) }\end{array}$ \\
\hline 10 & 9 & + & $\begin{array}{l}\text { Activities that care for the country improve food resource habitats (Russell-Smith et al. 1997, McGregor et al. } \\
\text { 2010, Bliege Bird et al. 2013) }\end{array}$ \\
\hline 11 & 10 & + & $\begin{array}{l}\text { External support (money, transport, resources) improves the capacity to look after the country (Morrison 2007, } \\
\text { Altman and Kerins 2012) }\end{array}$ \\
\hline
\end{tabular}

from a positive community condition, or well-being. For this reason, two key additions are specified in model $\mathrm{B}$. The first is a link between effort (B2) and sentiment/connection/knowledge (B22), which provides a positive pathway linking subsistence activity to motivation in a manner consistent with the dynamics of model A. This reflects field observations of effort, which increases attachment to the locations for that effort and in turn provides additional motivation. The second is a condition related to the definition of frustration (B5), which notes that although not directly depicted with a link focused on subsistence motivation, frustration can also lead to a range of nonsubsistencerelated activities, which in turn limit available time. In this way, responses to community dysfunction can also include actions that will divert and/or decrease levels of subsistence.

\section{SYSTEM FEEDBACKS AND DYNAMICS}

The qualitative models were analyzed to identify positive and negative feedback cycles contributing to system dynamics and regulation. Some model variables act only as independent factors or system drivers, whereas others, denoted by asterisks in Figs. 1 and 2, are involved in system feedback cycles. Each variable is assumed to have some degree of self-regulation (i.e., negative selfeffect), whereby its level or intensity is determined in part by features or processes that are intrinsic to the variable itself. For example, the distribution of catch (A3) is controlled not only by the amount of available catch, but also by social norms and customs that dictate the degree to which catch is shared within a distributional network (Altman and Peterson 1988, Peterson 1993, Bliege Bird and Bird 1997, Barber 2005).
Fig. 1. Generalized model of aquatic subsistence activity in indigenous communities of North Australian river catchments. See Tables 1 and 2 for descriptions of model nodes and links. Asterisks denote model nodes that contribute to system feedback cycles.

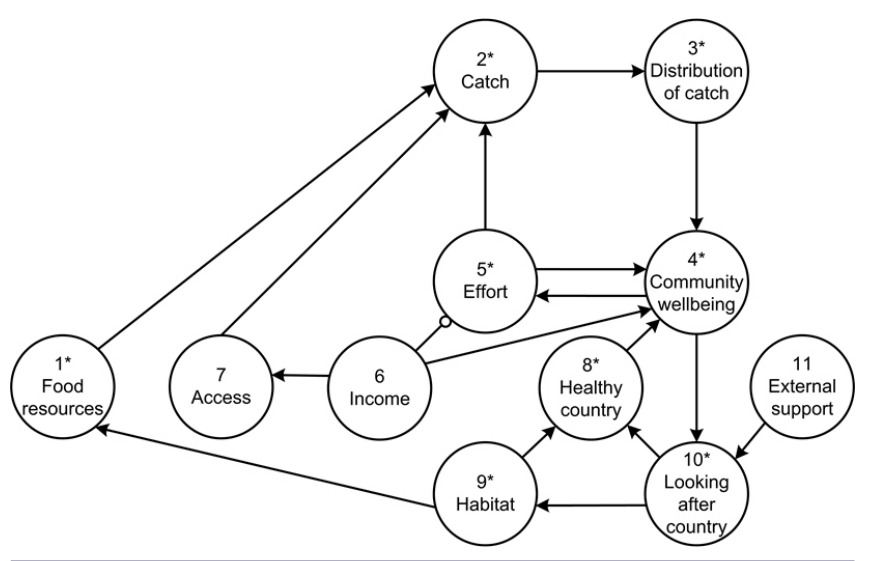

\section{Positive feedback cycles in model A}

Model A has only positive feedbacks for cycles of length two or greater, so for this model to achieve a state of equilibrium generally requires the variables to be strongly self-regulated. A central feature is that community well-being is involved in all feedback cycles, and all feedback cycles of length two or greater 
Table 3. Definition of nodes in model B.

\begin{tabular}{|c|c|c|}
\hline Node & Node title & Explanation and supporting literature \\
\hline 1 & Time & $\begin{array}{l}\text { Time available for hunting once higher priority activities have been undertaken (McCarthy } \\
\text { and McArthur 1960, Altman 1987). }\end{array}$ \\
\hline 2 & Effort & $\begin{array}{l}\text { The time and physical energy allocated to subsistence hunting (McCarthy and McArthur } \\
\text { 1960, Meehan 1982, Altman 1987, Codding et al. 2011). }\end{array}$ \\
\hline 3 & Catch & $\begin{array}{l}\text { Food and other resources obtained (Altman 1987, Povinelli 1992, Barber 2004, Jackson et al. } \\
2012 a \text { ). }\end{array}$ \\
\hline 4 & Community dysfunction & $\begin{array}{l}\text { Compound term that is the inverse of well-being, encompassing poor individual mental and } \\
\text { physical health, low levels of social and cultural health, and high levels of tension and } \\
\text { conflict in domestic, familial, and community settings (Zubrick et al. 2004, Carson et al. } \\
\text { 2007, Dockery 2010, Biddle and Swee 2012). }\end{array}$ \\
\hline 5 & Frustration & $\begin{array}{l}\text { Emotional state driven by negative assessments of individual and collective community life } \\
\text { (Purdie et al. 2010). }\end{array}$ \\
\hline 6 & Ancestral/ceremonial obligations & $\begin{array}{l}\text { Customary religious activities can have complex effects on subsistence by taking time, } \\
\text { increasing demand (e.g., provisioning temporary visitors), and/or increasing motivation } \\
\text { through enhancing connectedness with and knowledge of the surrounding landscape } \\
\text { (Morphy 1984, Altman 1987, Rose 2000, Morphy and Morphy 2012). }\end{array}$ \\
\hline 7 & Motivation & $\begin{array}{l}\text { Defined here as subsistence motivation, the mental state that drives effort. Motivation is now } \\
\text { an important aspect of contemporary subsistence, which is no longer the sole, or even } \\
\text { primary, source of food and other necessities. }\end{array}$ \\
\hline 8 & Species desirability & $\begin{array}{l}\text { Incorporates preferences for species (Toussaint 2014) and/or for particular biological states } \\
\text { of that species, i.e., young, fat, large, (Rouja et al. 2003). Species may be desirable year- } \\
\text { round, but desirability can also be highly seasonal (Woodward et al. 2012). The customary } \\
\text { and conservative elements of indigenous lives are often emphasized, but the targeting of } \\
\text { non-native species (Jackson et al. 2012a) shows how subsistence practices continue to evolve. }\end{array}$ \\
\hline 9 & Social security support & Income flows from state sources that are not tied to time-consuming activities. \\
\hline 10 & Income & $\begin{array}{l}\text { Money derived from employment, social security support, royalties, etc. (Daly 1992, Daly } \\
\text { and Hawke 1993). }\end{array}$ \\
\hline 11 & Employment and adult education & $\begin{array}{l}\text { Time-consuming activities that generate income. This includes programs that require work } \\
\text { for the provision of state income. }\end{array}$ \\
\hline 12 & Transport & $\begin{array}{l}\text { Cars, boats, and other vehicles that aid mobility. These are separate from access because of a } \\
\text { separately defined influence on their distribution (Altman 1987, Barber 2005, Fogarty 2005, } \\
\text { Altman and Hinkson 2007). }\end{array}$ \\
\hline 13 & Access & $\begin{array}{l}\text { Capacity to reach habitats where effort can be expended (Altman 1987, Barber 2004, Altman } \\
\text { and Hinkson 2007). }\end{array}$ \\
\hline 14 & Social network & Levels of connection between active subsistence hunters and others. \\
\hline 15 & Distributional network & $\begin{array}{l}\text { The people with whom subsistence returns are shared, predominantly kin and co-residents of } \\
\text { the sharer (Altman 1987, Peterson 1993, Barber 2005). }\end{array}$ \\
\hline 16 & Environmental restrictions & Physical barriers (e.g., flooding, heat) that constrain access (Ulijaszek 2001, Barber 2005). \\
\hline 17 & Cultural and ceremonial restrictions & $\begin{array}{l}\text { May be geographical restrictions on access and/or food category prohibitions and taboos, } \\
\text { both affecting desirability (Altman 1987, Barber 2004, Toussaint 2014). }\end{array}$ \\
\hline 18 & Nonindigenous barriers & $\begin{array}{l}\text { Barriers generated by past colonization and contemporary nonindigenous tenure regimes } \\
\text { (Williams 1986, Rose 1996, Baker 1999, Barber 2010, 2013) and by less formal influences } \\
\text { with similar effects (e.g., voluntary avoidance of areas heavily frequented by nonindigenous } \\
\text { people; Barber and Jackson } 2011 \text { b). }\end{array}$ \\
\hline 19 & Noncustomary religious obligations & $\begin{array}{l}\text { Religious services and associated activities (Loos 2007, Magowan 2007). Usually Christian, } \\
\text { these often take place on weekends, which is an otherwise important time for subsistence } \\
\text { activity. }\end{array}$ \\
\hline 20 & Domestic responsibilities & $\begin{array}{l}\text { Paid domestic help is extremely rare in indigenous Australia, resulting in domestic work } \\
\text { limiting time available for other activities. The node includes attending to health and family } \\
\text { issues, both of the hunter and their dependants. }\end{array}$ \\
\hline 21 & Social and recreational activity & $\begin{array}{l}\text { Any activity that diverts time and energy from hunting, e.g., television, sports, games, } \\
\text { gambling, music, recreational drug use, etc. }\end{array}$ \\
\hline 22 & Sentiment, connection, and knowledge & $\begin{array}{l}\text { Personal attitudes, abilities, emotions, and familiarities with respect to the surrounding } \\
\text { country that increase subsistence motivation (Rose 1996, 2000, Barber 2005). }\end{array}$ \\
\hline 23 & Species availability & $\begin{array}{l}\text { Incorporates distribution, abundance, and the ability to be caught (Meehan 1982, Altman } \\
\text { 1987, Bliege Bird and Bird 2008). Availability can be heavily influenced by season (Clarke } \\
\text { 2009, Prober et al. 2011, Woodward et al. 2012). }\end{array}$ \\
\hline 24 & Habitat & $\begin{array}{l}\text { The areas or environments in which target species live (Yingguny Lindsay et al. 2001, } \\
\text { Roberts et al. 2011). The influences of nonindigenous people and activities on biophysical } \\
\text { systems are not included in this model, but may be highly significant factors for both habitat } \\
\text { and species availability. }\end{array}$ \\
\hline
\end{tabular}


Table 4. Definition and explanation of links in model B.

\begin{tabular}{|c|c|c|c|}
\hline $\begin{array}{l}\text { From } \\
\text { node }\end{array}$ & To node & $\begin{array}{c}\text { Direction of } \\
\text { effect }\end{array}$ & Explanation and supporting literature \\
\hline 1 & 2 & + & Time is required for effort (Altman 1987) \\
\hline 2 & 1 & - & Effort decreases available time \\
\hline 2 & 3 & + & Effort influences catch \\
\hline 2 & 4 & - & Effort reduces frustration through physical exertion and time spent away from the settlement (Barber 2005) \\
\hline 2 & 5 & - & Effort reduces dysfunction through physical exertion and time away from the settlement (Barber 2005) \\
\hline 3 & 4 & + & $\begin{array}{l}\text { Successful catch reduces dysfunction; this assumes the social and nutritional benefit of distributing the catch } \\
\text { outweighs the potential negative consequences of conflicts about resource distribution (Gould 1982, Altman } \\
\text { 1987, Altman and Peterson 1988, Barber 2005, Saethre 2011, Peterson 2013) }\end{array}$ \\
\hline 3 & 7 & + & $\begin{array}{l}\text { Successful catch influences motivation, encouraging further attempts (Barber 2004, Jackson et al. 2011); } \\
\text { assumes that satiation from existing catch is only temporary due to limited shelf-life of goods, wide } \\
\text { distribution, and/or rapid consumption }\end{array}$ \\
\hline 4 & 5 & + & Community dysfunction influences frustration \\
\hline 5 & 7 & + & $\begin{array}{l}\text { Frustration influences motivation, as active hunters relieve frustration with community life by escaping to } \\
\text { undertake subsistence (Barber 2005, Walker 2010). Such frustration manifests itself in a range of other ways } \\
\text { (Purdie et al. 2010), including through social and recreational activity and regional mobility. However, the focus } \\
\text { of this model of the subsistence drivers on healthy, active hunters means that these effects (which may be } \\
\text { substantial) are assumed rather than actively depicted. This link should also be understood as a driver of } \\
\text { limited duration; model A demonstrates the importance of a level of community well-being for the } \\
\text { maintenance of long-term subsistence }\end{array}$ \\
\hline 6 & 1 & - & Customary religious obligations decrease subsistence time available (Altman 1987, Barber 2005) \\
\hline 6 & 2 & + & Customary religious obligations influence effort by increasing demand for resources (Altman 1987) \\
\hline 6 & 7 & + & Customary religious obligations increase demand, influencing motivation (Altman 1987) \\
\hline 7 & 2 & + & Motivation drives effort \\
\hline 8 & 3 & + & Species desirability influences catch (Jackson et al. 2012a) \\
\hline 8 & 7 & + & Species desirability influences motivation (Jackson et al. 2012a, Woodward et al. 2012) \\
\hline 9 & 1 & + & Social security support income reduces the need for employment, increasing time available for subsistence \\
\hline 9 & 10 & + & Social security support provides income \\
\hline 10 & 7 & - & $\begin{array}{l}\text { Income influences motivation by providing alternative sources of food (Smith and Smith 1999, Saethre 2005, } \\
\text { Scelza et al. 2014) }\end{array}$ \\
\hline 10 & 12 & + & Income increases transport availability (Altman 1987, Barber 2005) \\
\hline 11 & 10 & + & Employment provides income \\
\hline 11 & 1 & - & Employment decreases time available \\
\hline 12 & 13 & + & Available transport influences access (Povinelli 1992, Barber 2005) \\
\hline 12 & 15 & + & Available transport influences distributional network (Barber 2005) \\
\hline 13 & 2 & + & Access influences effort (Barber 2005) \\
\hline 14 & 12 & + & Social network influences opportunities for transport (Long and Memmott 2005) \\
\hline 14 & 15 & + & Social network influences the number of potential receivers \\
\hline 15 & 2 & + & Distributional network influences effort needed to supply it (Altman 1987, Barber 2005) \\
\hline 16 & 13 & - & Physical barriers influence access \\
\hline 17 & 13 & - & Geographically based cultural and ceremonial restrictions influence access (Morphy 2004) \\
\hline 17 & 8 & - & $\begin{array}{l}\text { Species- or category-based cultural and ceremonial restrictions influence desirability (Altman 1987, Toussaint } \\
\text { 2014) }\end{array}$ \\
\hline 18 & 13 & - & Nonindigenous tenure barriers and effects on land and water influence access \\
\hline 19 & 1 & + & Noncustomary religious obligations decrease available time \\
\hline 20 & 1 & - & Domestic obligations decrease available time \\
\hline 21 & 1 & - & Social activities decrease available time \\
\hline 22 & 7 & + & Sentiment about, connectedness to, and knowledge of landscape influence motivation (Barber 2005) \\
\hline 23 & 3 & + & Availability influences catch (Jackson et al. 2012a) \\
\hline 23 & 8 & + & Availability influences desirability through regulating returns for effort (Barber 2005) \\
\hline 24 & 23 & + & Extent of available habitat influences the presence of available species \\
\hline
\end{tabular}

are composed of positive links; hence, all variables will react uniformly to a perturbation (i.e., all increasing or decreasing together). The resulting equilibrium dynamics are that all variables act mutually to reinforce either of two alternative states (Dambacher and Ramos-Jiliberto 2007, Marzloff et al. 2011): an elevated state, with high levels of community well-being, high hunting participation rates, high rates of management of country, etc.; or a degraded state, with low levels of community well-being, etc. The following are the positive feedback cycles in model A.
1. Community well-being (A4) - effort (A5)

2. Community well-being (A4) - looking after country (A10)healthy country (A8)

3. Community well-being (A4) - effort (A5) - catch (A2) distribution of catch (A3)

4. Community well-being (A4) - looking after country (A10) habitat (A9) - healthy country (A8)

5. Community well-being (A4) - looking after country (A10) food resources (A1) - catch (A2) - distribution of catch (A3) 
Fig. 2. Generalized model of factors regulating aquatic subsistence by active adult indigenous hunters in North Australian river catchments. See Tables 3 and 4 for descriptions of model nodes and links. Asterisks denote model nodes that contribute to system feedback cycles.

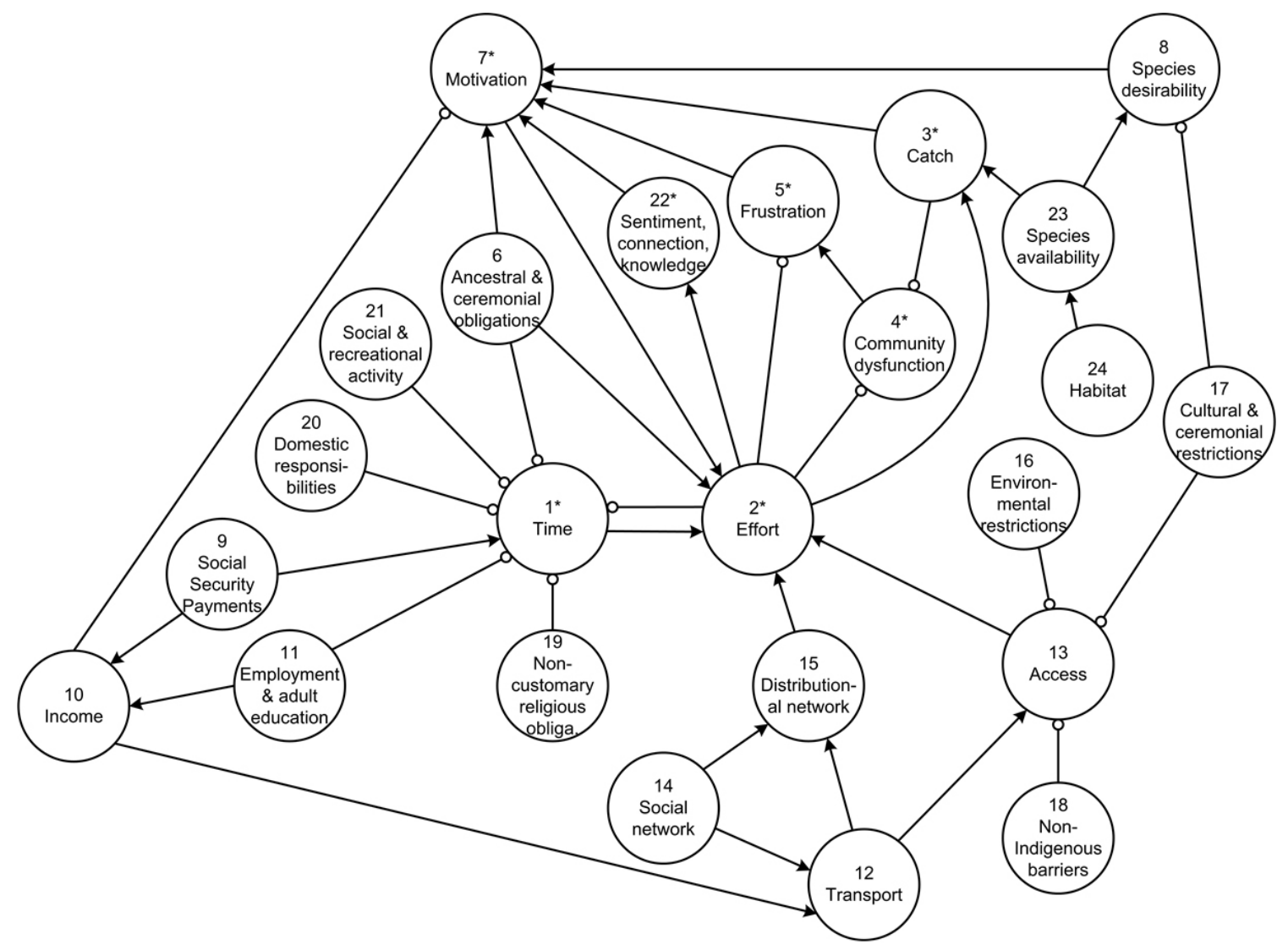

Negative and positive feedback cycles in model $B$

Model B has both negative and positive feedback cycles. Stability in this system requires that the strength of the two positive feedback cycles is less than the combined strength of the four negative feedback cycles. Reflecting the orientation of the study, effort (A2) is involved in all feedback cycles, both positive and negative. Of the negative feedback cycles, time (A1) is combined with effort (A2) to create the shortest cycle of length two, whereas frustration (A5) is involved with each of the longer cycles. This model has effort (A2) driving catch (A3) as well as sentiment, connection, and knowledge (A22), which leads to increased motivation (A7) and further effort (A2). This self-enhancing dynamic is held in check by the general limitation of time from competing activities or responsibilities (A6, A19-21), but also by stimulus-response feedback that involves dissipation of frustration (A5) at both personal (i.e., second negative feedback cycle) and community levels (i.e., third and fourth negative feedback cycles).

The following are the negative feedback cycles in model B.

1. Effort (B2) - time (B1)

2. Effort (B2) - frustration (B5) - motivation (B7)

3. Effort (B2) - community dysfunction (B4) - frustration (B5) - motivation (B7)
4. Effort (B2) - catch (B3) - community dysfunction (B4) frustration (B5) - motivation (B7)

The following are the positive feedback cycles in model B.

1. Effort (B2) - catch (B3) - motivation (B7)

2. Effort (B2) - sentiment, connection, knowledge (B22) motivation (B7)

\section{INTERVENTION AND PERTURBATION ANALYSIS}

Table 5 contains the results of the perturbation analyses. For the perturbation involving an increase in community dysfunction (B4), there is a predicted decrease in available time for subsistence activities (B1) and an increase in effort (B2), catch (B3), motivation (B7), and sentiment connection and knowledge (B22). The predicted levels of community dysfunction (B4) and frustration (B5), however, are highly ambiguous and could be either at a higher or lower level compared to pre-perturbation levels. Degradation of floodplain habitats (B24) is predicted to cause a decrease in levels of catch (B3) and an increase in levels of community dysfunction (B4) and frustration (B5), whereas the predicted responses of the other variables are ambiguous. Similarly, a decrease in social security payments (B9) is also predicted to increase community dysfunction (B4) and frustration (B5), but generates a decrease in effort (B2), catch (B3), and sentiment/connection/knowledge (B22). Finally, an increase in 
Table 5. Predictions of qualitative response of select variables in model B to four perturbation scenarios. Predicted responses in terms of direction of change $(+$, increase; - , decrease) in model variables; ambiguous predictions with a relatively high probability of sign determinacy $(\geq 0.85)$ are enclosed in parentheses; and "?" denotes predictions with low probability.

\begin{tabular}{|c|c|c|c|c|c|c|c|}
\hline Perturbation scenario & Time & Effort & Catch & $\begin{array}{l}\text { Community } \\
\text { dysfunction }\end{array}$ & $\begin{array}{l}\text { Frustra- } \\
\text { tion }\end{array}$ & $\begin{array}{l}\text { Sentiment, } \\
\text { connection, } \\
\text { knowledge }\end{array}$ & Motivation \\
\hline Increase in community dysfunction & - & + & + & $?$ & $?$ & + & + \\
\hline Increase in habitat degradation & $?$ & $?$ & $(-)$ & $(+)$ & $(+)$ & $?$ & $?$ \\
\hline Decrease in social security payments & $?$ & $(-)$ & $(-)$ & $(+)$ & $(+)$ & $(-)$ & $?$ \\
\hline Increase in access & - & + & + & - & - & + & $?$ \\
\hline
\end{tabular}

access (B13) is predicted to increase effort (B2), catch (B3), and sentiment/connection/knowledge (B22), and decrease levels of available time (B1), community dysfunction (B4) and frustration (B5).

\section{DISCUSSION}

Australian indigenous subsistence systems have been of interest to scholars and researchers for many decades, resulting in a rich and diverse literature, particularly in the northern half of the continent. However, formal models of the influencing conditions and drivers of that activity remain rare. Such models enable the complexity and significance of subsistence activities to be represented and for key drivers and systemic properties to be identified, defined, causally related, and debated. The qualitative models generated here are preliminary, but they are useful for multiple reasons: they formally demarcate primary nodes and links; they identify key relationships (which in some cases are relatively under-researched and under-documented); they allow analysis of systemic and emergent qualities of the models as constructed; and they allow preliminary evaluations of responses to selected perturbations. Future extensions to such work may compare the degree of fit between the qualitative models and particular geographic case studies and/or between the models and the perspectives of indigenous subsistence hunters themselves.

The decision to model both the longer term persistence of subsistence at a community level (model A) and the drivers of activity undertaken by active individual hunters on shorter time frames (model B) was an important step in generating different perspectives regarding subsistence. However, it also raises key issues for subsequent analysis, most notably the potential complementarities and contradictions in the relationship between the two models operating at different time scales (Ertsen et al. 2014). Both models are generated by the same team using the same information sources, and thus, are generally consistent with one another in many key respects. Nevertheless, one model emphasizes the importance of community well-being (A4) as a foundation for ongoing subsistence activity, whereas the other characterizes at least some hunting and fishing by key individuals as arising out of frustration with community dysfunction (B4). The pathways to motivation depicted in model $\mathrm{B}$ are more complex than just this one negative avenue, with the most important counterbalance being the positive pathway depicting effort (B2) influencing sentiment/connection/knowledge (B22) and thereby motivation (B7). Nor are positive and negative drivers mutually exclusive: a particular instance of effort can be driven by sentiment about a hunting locality (or an activity at a range of localities) as well as a level of frustration with community life. In presenting model $\mathrm{B}$ as constructed, we do not argue that the dysfunction-frustration pathway is the primary motivator of subsistence effort, but we do assert that it is observationally significant enough to be represented in a model depicting the drivers of subsistence by individual hunters. This kind of motivation has also been publicly identified by indigenous people themselves; for example, an international film co-produced and scripted by people from a remote area of northern Australia depicts a key protagonist electing to go hunting as a response to domestic strife (de Heer and Djigirr 2006).

However, as model A clearly indicates, dysfunction does not seem plausible as a primary driver for the persistence of communitywide subsistence over longer time frames. What this highlights is the need for further work that conceptualizes and interrogates effort and motivation at the interfaces between positive and negative assessments of community condition, between community and individual scales, and over longer and shorter time frames. Effort may be driven by community dysfunction and may in turn play a role in mitigating the subsequent effects of that dysfunction, but this empirically observable phenomenon is insufficient to account for the complexity and persistence of contemporary indigenous subsistence. That significant national and international attention is being paid to levels of community dysfunction in remote indigenous Australian contexts and how it can be minimized, including through investments in environmental programs and action (Barber and Jackson 2011c, Altman and Kerins 2012), further emphasizes the need to understand its potentially complex relationships with subsistence activity.

The emergent system feedbacks and dynamics identified in the models provide an additional level of potential analysis. The positive feedbacks in model A that encourage one of two alternate states highlight key interdependencies that are consistent with indigenous perspectives; community well-being (A4) cannot be maintained unless: the country itself is healthy (A8); appropriate people are looking after it (A10) through practices that encompass subsistence effort (A5); and the results of such productive labor are appropriately distributed (A3). From such a perspective, indigenous desires for holistic and community-driven social and environmental management programs are clearly comprehensible. Conversely, so is the difficulty of shifting from a state of entrenched disadvantage without simultaneously addressing multiple factors, including rights to access, use, manage, and distribute natural resources. 
The system dynamics of model B are more complex and more ambiguous, reflecting the multiple influences on subsistence effort by key individuals. Sentiment and connection toward landscapes (B22) combines with the prospect of successful returns (B3) to create consistent positive feedback affecting effort (B2). The primary negative feedback with respect to effort (B2) is available time (B1). The other longer feedbacks, which emerge as negative in terms of model dynamics, actually reflect the suppression of negatively defined variables that affect motivation (B7) and subsequently, effort (B2), frustration (B5), and community dysfunction (B4). This indicates how these negatively defined variables are present and can account for particular instances of effort (B2), but cannot of themselves provide a sufficient basis for ongoing subsistence activity over longer time frames. Undertaking effort (B2) suppresses these negative drivers of subsequent effort, whereas it strengthens the primary positive cycle associated with sentiment, knowledge, and connection (B22). In this way, the dynamics of the model reflect the complex influences on individual motivation and suggest how they relate to broader community-scale patterns.

Although the qualitative models depicted here are deliberately conceptual and general, the choice of perturbations (Table 5) applied to model B do reflect current trends and relevant priorities. Demographically, the number of young indigenous people residing in areas with very limited employment prospects is growing rapidly, creating challenges for social and communal cohesion. In model $\mathrm{B}$, an increasing level of community dysfunction (B4) can drive effort, motivation, etc., of active adult hunters, but this limited effect must be set against the wider context presented in model A, which makes it clear that increasing dysfunction (i.e., declining well-being) is not a plausible sustainable long-term driver of community subsistence. Further work in characterizing this set of relationships is clearly required.

Concerns with dysfunction and demographics underlie a second perturbation scenario of reductions in social security payments (Table 5). Changing political attitudes to social welfare and the economic pressures associated with an ageing population may plausibly lead to a broad reduction in social support across Australian society generally, and in indigenous communities in particular. In model B, the effects on subsistence of such a change are ambiguous, but decreases in effort levels and increases in dysfunction are one potential consequence. This suggests that, should social security support (B9) decrease, subsistence effort (B2) by key individuals may come under pressure despite the increased demand for foods obtainable without a direct cash transfer. Food pricing and food security are significant issues in regional and remote Australia: $45 \%$ of indigenous people in the Northern Territory reported running out of food in the previous 12 months, compared with a national average of 5\% (Australian Health Ministers' Advisory Council 2008). State recognition of the value of subsistence can also support alternative social security outcomes; in James Bay, Canada, for example, state income support is provided for productive subsistence hunters and trappers who do not earn adequate cash income (Ferguson 2011). In model B, the ambiguous effect on subsistence of reduced social security suggests that the relationship between such payments and subsistence in hybrid economies (Altman 2009) is complex, and therefore, that responses to alterations in social security support may be equally complex.
The scenario that suggests habitat (B24) degradation as having potentially deleterious effects on motivation (B7) and effort (B2) is consistent with our expectations and highlights two areas of policy significance. One area is land and wider catchment management, and indigenous peoples' roles in those processes (Altman and Kerins 2012). The second area is the importance of water planning and allocation at a time when both water developments and climatic changes may result in significant changes in the volume and/or timing of water flows through north Australian river systems. The predicted responses to the degradation of habitat suggests that ongoing subsistence, and the indigenous identities it helps to sustain, requires effective management of land, riparian corridors, and water flows (Jackson 2011, Jackson and Barber 2013, Liedloff et al. 2013).

Lastly, the scenario of increasing access (B13) reflects real developments in indigenous access to and ownership of land over recent decades in northern Australia (Holmes 2010). Various processes have increased access opportunities for indigenous people: grants under traditional land rights processes, purchases of land by statutory and other development funds for subsequent transfer to indigenous people, private purchases, and specific rights of access for subsistence purposes to land owned by others. From this perspective, the trend for increasing formal access by indigenous people seems likely to continue, and the perturbation suggests that this alone will positively influence effort (B2), with some potential implications for population and catch (B3) levels (Barber et al. 2014). However, the effects on effort (B2) may be more ambiguous if increasing access (B13) is combined with other changes such as lower incomes (B10) or decreases in available time (B1).

These perturbation scenarios are conceptualized as changes in one location through time, as evaluations of temporal variation. With respect to geographic variation, the constituents of the qualitative models outlined here are sufficiently general to be applicable for testing in other nonmarket resource use contexts, including nonindigenous ones. However, we would note one crucial qualification to that potential highlighted by other recent projects focused on modeling indigenous Australian fishing in the Torres Strait (Busilacchi et al. 2013, van Putten et al. 2013). The qualitative models depicted here assume no significant commercial market in the subsistence target species, whereas van Putten et al. (2013) describe a mixed commercial, recreational, and subsistence indigenous lobster fishery that is heavily influenced by the associated commercial lobster market; the resulting model contains pronounced economic drivers such as price and infrastructure. A second study from the Torres Strait (Busilacchi et al. 2013) provides significant data linking wider fishing effort on three islands to income from both public (a state employment program) and private (commercial fishery and private employment) sources. In both studies, the link between subsistence and the wider socioeconomic context is emphasized, and the presence of commercial markets plays a substantial role in the observed activity.

The presence of commercial effort is important for model applicability not just because of its direct interaction with subsistence effort, but also because it directly affects the existing assumption that indigenous effort has a negligible ecological effect at the catchment scale. One effect of this assumption is that 
the ecological and social subsystems are not so strongly interlinked, but in a more highly populated region where commercial markets were driving higher levels of resource extraction, the models would need to show these feedbacks more clearly. The recent modeling of self-management behavior among abalone fishers in southern Australia (Gilmour et al. 2013) is an important example in this respect, showing how known biological constraints can alter human fishing behavior in complex ways. In the current qualitative models, the main way in which indigenous people affect the health of the ecological system is through their own land management activities. Framing subsistence activities as socio-cultural rather than predominantly economic phenomena (Wheeler and Thornton 2005) can be a valuable step, but the absence of overt commercial activity and the assumptions about the effects of subsistence effort on natural resources means that the models presented here may require careful modification and refinement before they are applicable to the wide array of conditions in which commercial markets play a significant role.

\section{CONCLUSION}

Other recent studies from north Australia (Stoeckl et al. 2013, Close et al. 2014) have shown that in-depth knowledge of the dynamic feedbacks between human and aquatic systems has remained elusive. Conceptual models that effectively internalize processes of decision-making, social power, and economic flows (Birkenholtz 2012) can reveal feedbacks that depict social action, reaction, and adaptation to perturbations such as changes to income or environmental degradation. The significance and complexity of contemporary subsistence depicted in the qualitative models represented here underscore the need for careful attention to local circumstances and local aspirations. Participatory modeling has been shown to be useful in generating inclusive dialog about system components and management interventions (Tidwell et al. 2004, Jackson et al. 2012b, Barber and Jackson 2015), as well as in fostering broader and longer term social learning (Hare 2011). A participatory modeling process that incorporates the views and knowledge of indigenous participants as part of a move from generic to specific representations would be a logical next step.

Such a participatory process may result in new insights, unexpected results, challenges to assumptions, and model reconceptualization, as well as build familiarity and local specificity into the generalized structures. Qualitative modeling obliges participants to reflect on assumptions about cause-andeffect relationships, and the potential challenge of local community participation to the materialist assumptions underpinning the current models has already been noted. Nevertheless, common ground can exist alongside such points of difference, and the results demonstrate the wide array of influences on aquatic resource use, even at the coarsest and most generic levels of specification. The models graphically represent the wider socio-cultural and economic context for indigenous Australian aquatic resource use, enabling further analysis of key relationships, key geographic contexts, and future scenarios regarding the persistence of subsistence.

\section{Footnote}

1. No one term is entirely appropriate, but we emphasize the phrase "aquatic subsistence" to encompass a range of waterdependent practices, including fishing, hunting freshwater turtles and aquatic birds, gathering aquatic or riverine plants for sustenance or medicinal purposes, collecting materials for traditional arts and crafts, etc. The primary focus of aquatic activity is usually food provision, but not always. The models may be generalizable to subsistence activity in other landscapes, but aquatic resources are the primary focus here.

Responses to this article can be read online at: http://www.ecologyandsociety.org/issues/responses. $\mathrm{php} / 7244$

\section{Acknowledgments:}

The authors acknowledge the indigenous individuals, groups, and communities across northern Australia whose support for and participation in a wide array of research projects provided the context for this paper. We also acknowledge the input of colleagues undertaking a related modeling study (Liedloff et al. 2013). Funding for this research was provided by the Water for a Healthy Country Flagship of the CSIRO and by Commonwealth government through the Northern Hub of the National Environmental Research Program. We thank multiple anonymous reviewers and the journal editors for critical commentary and suggestions that substantially improved the manuscript. Any remaining errors are the responsibility of the authors.

\section{LITERATURE CITED}

Altman, J. 1983. Eastern Gunwinggu fish trapping at Gunbatgarri. The Beagle, Occasional Papers of the Northern Territory Museum 1:59-71.

Altman, J. 1987. Hunter-gatherers today: an Aboriginal economy in North Australia. Australian Institute of Aboriginal Studies, Canberra, Australia.

Altman, J. 2009. The hybrid economy and anthropological engagements with policy discourse: a brief reflection. Australian Journal of Anthropology 20(3):318-329. http://dx.doi.org/10.1111/ j.1757-6547.2009.00039.x

Altman, J., and M. Hinkson. 2007. Mobility and modernity in Arnhem Land: the social universe of Kuninjku trucks. Journal of Material Culture 12(2):181-203. http://dx.doi.org/10.1177/1359183507078122

Altman, J., K. Jordon, S. Kerins, G. Buchanan, N. Biddle, E. Ens, and K. May, editors. 2009. Indigenous interests in land and water. CSIRO, Canberra, Australia.

Altman, J., and S. Kerins, editors. 2012. People on country: vital landscapes, indigenous futures. Federation Press, Sydney, Australia.

Altman, J., and N. Peterson. 1988. Rights to game and rights to cash among contemporary Australian hunter-gatherers. Pages 75-94 in T. Ingold, D. Riches, and J. Woodburn, editors. Hunters and gatherers. Volume 2: property, power and ideology. Berg, Oxford, UK.

Anderson, I. 1996. Aboriginal well-being. Pages 53-73 in C. Grbich, editor. Health in Australia: sociological concepts and issues. Pearson/Longman, Sydney, Australia. 
Australian Health Ministers' Advisory Council. 2008. Aboriginal and Torres Strait Islander health performance framework 2008 report. Commonwealth of Australia, Canberra, Australia. [online] URL: http://www.aihw.gov.au/publication-detail/? $\underline{i d=6442468199}$.

Baker, R. 1999. Land is life: from bush to town: the story of the Yanyuwa people. Allen and Unwin, Sydney, Australia.

Baker, R., J. Davies, and E. Young, editors. 2001. Working on country: contemporary indigenous management of Australia's lands and coastal regions. Oxford University Press, Melbourne, Australia.

Barber, M. 2004. Report of observation: Yilpara community and Blue Mud Bay from October 2000-November 2001 and JuneDecember 2002. Report to the Federal Court of Australia. Australian National University, Canberra, Australia. [online] URL: http://researchonline.jcu.edu.au/1701/2/BarberBMBFINAL-1. pdf.

Barber, M. 2005. Where the clouds stand: Australian Aboriginal attachments to water, place, and the marine environment in Northeast Arnhem land. Dissertation. Australian National University, Canberra, Australia.

Barber, M. 2010. Coastal conflicts and reciprocal relations: encounters between Yolngu people and commercial fishermen in Blue Mud Bay, north-east Arnhem Land. Australian Journal of Anthropology 21(3):298-314. http://dx.doi.org/10.1111/ j.1757-6547.2010.00098.x

Barber, M. 2011. 'Nothing ever changes': historical ecology, causality and climate change in Arnhem Land, Australia. Pages 89-100 in Y. Musharbash and M. Barber, editors. Ethnography and the production of anthropological knowledge: essays in honour of Nicolas Peterson. ANU ePress, Canberra, Australia.

Barber, M. 2013. Indigenous water values, rights and interests in the Flinders and Gilbert catchments. A technical report to the Australian Government from the CSIRO Flinders and Gilbert Agricultural Resource Assessment, part of the North Queensland Irrigated Agriculture Strategy CSIRO Water for a Healthy Country and Sustainable Agriculture flagships, Canberra, Australia. [online] URL: https://publications.csiro.au/rpr/ download?pid=csiro:EP1310971\&dsid=DS4.

Barber, M., and S. Jackson. 2011a. Aboriginal water values and resource development pressures in the Pilbara region of northwest Australia. Australian Aboriginal Studies 2011(2):32-50.

Barber, M., and S. Jackson. 2011b. Indigenous water values and water planning in the Upper Roper River, Northern Territory. CSIRO, Darwin, Australia. [online] URL: http://www.csiro.au/ / media/CSIROau/Flagships/Water $\% 20$ for $\% 20 \mathrm{a} \% 20$ Healthy $\% 20$ Country $\%$ 20Flagship/Indigenous-Water-Roper-River/WfHC_Roper $\% 20$ River $\%$ 20Report $\%$ 20December $\% 202011$.pdf.

Barber, M., and S. Jackson. 2011c. Water and indigenous people in the Pilbara, Western Australia: a preliminary study. CSIRO, Darwin, Australia. [online] URL: http://www.csiro.au/ /media/ CSIROau/Files/PDF/p12ei.pdf.

Barber, M., and S. Jackson. 2012. Indigenous water management and water planning in the Upper Roper River, Northern Territory: history and implications for contemporary water planning. CSIRO, Darwin, Australia. [online] URL: http://www.csiro.au/ /media/ CSIROau/Flagships/Water $\% 20$ for $\% 20 \mathrm{a} \% 20$ Healthy $\% 20$ Country $\%$ 20Flagship/Indigenous-Water-Roper-River/IndigenousWaterManagementReportApril2012.pdf.

Barber, M., and S. Jackson. 2014. Autonomy and the intercultural: interpreting the history of Australian Aboriginal water management in the Roper River catchment, Northern Territory. Journal of the Royal Anthropological Institute 20 (4):670-693. http://dx. doi.org/10.1111/1467-9655.12129

Barber, M., and S. Jackson. 2015. 'Knowledge making': issues in modelling local and indigenous ecological knowledge. Human Ecology 43(1):119-130. http://dx.doi.org/10.1007/s10745-015-9726-4

Barber, M., S. Jackson, J. Shellberg, and V. Sinnamon. 2014. Working knowledge: characterising collective indigenous, scientific, and local knowledge about the ecology, hydrology and geomorphology of Oriners Station, Cape York Peninsula, Australia. Rangeland Journal 36(1):53-66. http://dx.doi. org/10.1071/RJ13083

Biddle, N., and H. Swee. 2012. The relationship between wellbeing and indigenous land, language and culture in Australia. Australian Geographer 43(3):215-232. http://dx.doi. org/10.1080/00049182.2012.706201

Biernoff, D. 1978. Safe and dangerous places. Pages 93-106 in L. R. Hiatt, editor. Australian aboriginal concepts. Australian Institute of Aboriginal Studies and Humanities Press, Canberra, Australia.

Birkenholtz, T. 2012. Network political ecology: method and theory in climate change vulnerability and adaptation research. Progress in Human Geography 36(3):295-315. http://dx.doi. org/10.1177/0309132511421532

Bliege Bird, R. L., and D. W. Bird. 1997. Delayed reciprocity and tolerated theft: the behavioral ecology of food-sharing strategies. Current Anthropology 38(1):49-78. http://dx.doi.org/10.1086/204581

Bliege Bird, R., and D. W. Bird. 2008. Why women hunt: risk and contemporary foraging in a Western Desert aboriginal community. Current Anthropology 49:655-693. http://dx.doi. org/10.1086/587700

Bliege Bird, R., N. Taylor, B. F. Codding, and D. W. Bird. 2013. Niche construction and Dreaming logic: aboriginal patch mosaic burning and varanid lizards (Varanus gouldii) in Australia. Proceedings of the Royal Society B 280: 20132297. http://dx.doi. org/10.1098/rspb.2013.2297

Bradley, J. J. 1991. 'Li-Maramaranja': Yanyuwa hunters of marine animals in the Sir Edward Pellew Group, Northern Territory. Records of the South Australian Museum 25:91-110.

Bradley, J. 2001. Landscapes of the mind, landscapes of the spirit. Pages 295-304 in R. Baker, J. Davies, and E. Young, editors. Working on country: contemporary indigenous management of Australia's lands and coastal regions. Oxford University Press, Melbourne, Australia.

Bradley, J. 2010. Singing saltwater country: journey to the songlines of Carpentaria. Allen and Unwin, Crows Nest, Australia. 
Burgess, C. P., F. H. Johnston, H. L. Berry, J. McDonnell, D. Yibarbuk, C. Gunabarra, A. Mileran, and R. S. Bailie. 2009. Healthy country, healthy people: the relationship between Indigenous health status and "caring for country". Medical Journal of Australia 190(10):567-572.

Busilacchi, S., G. R. Russ, A. J. Williams, S. G. Sutton, and G. A. Begg. 2013. The role of subsistence fishing in the hybrid economy of an indigenous community. Marine Policy 37:183-191. http:// dx.doi.org/10.1016/j.marpol.2012.04.017

Carson, B., T. Dunbar, R. D. Chenhall, and R. Bailie, editors. 2007. Social determinants of indigenous health. Allen and Unwin, Crows Nest, Australia.

Carson, D., A. Taylor, and S. Campbell. 2009. Demographic trends and likely futures for Australia's tropical rivers. Land and Water Australia, Canberra, Australia. [online] URL: http://track.org. au/sites/default/files/managed/file-attach/biblio/TRaCK 3.1_CD$\underline{\mathrm{U} \text { Report final.pdf. }}$

Chase, A., and P. Sutton. 1981. Hunter-gatherers in a rich environment: Aboriginal coastal exploitation in Cape York Peninsula. Pages 1818-1852 in A. Keast, editor. Ecological biogeography of Australia. W. Junk, The Hague, The Netherlands.

Clarke, P. A. 2009. Australian Aboriginal ethnometeorology and seasonal calendars. History and Anthropology 20(2):79-106. http://dx.doi.org/10.1080/02757200902867677

Close, P. G., R. J. Dobbs, D. J. Tunbridge, P. C. Speldewinde, D. M. Warfe, S. Toussaint, and P. M. Davies. 2014. Customary and recreational fishing pressure: large-bodied fish assemblages in a tropical, intermittent Australian river. Marine and Freshwater Research 65(5):466-474. http://dx.doi.org/10.1071/MF13042

Codding, B. F., R. Bliege Bird, and D. W. Bird. 2011. Provisioning offspring and others: risk-energy trade-offs and gender differences in hunter-gatherer foraging strategies. Proceedings of the Royal Society B 278:2502-2509. http://dx.doi.org/10.1098/ $\underline{\text { rspb.2010.2403 }}$

Cooper, D., and S. Jackson. 2008. Preliminary study on Indigenous water values and interests in the Katherine Region of the Northern Territory. CSIRO, Darwin, Australia. [online] URL: http://www. csiro.au/ /media/CSIROau/Divisions/CSIRO $\% 20$ Sustainable $\%$ 20Ecosystems/IndigenousWaterValuesStudyReport CSE pdf $\%$ 20Standard.pdf.

Coyle, G. 2000. Qualitative and quantitative modelling in system dynamics: some research questions. System Dynamics Review 16 (3):225-244. http://dx.doi.org/10.1002/1099-1727(200023)16:3<225:: AID-SDR 195>3.0.CO;2-D

Daly, A. E. 1992. The determinants of Aboriginal employment income. CAEPR Discussion Paper 32/1992. CAEPR, Canberra, Australia. [online] URL: http://passthrough.fw-notify.net/ download/303339/http://caepr.anu.edu.au/sites/default/files/Publications/ DP/1992_DP32.pdf.

Daly, A. E., and A. E. Hawke. 1993. Work and welfare for indigenous Australians. CAEPR Discussion Paper 48/1993. CAEPR, Canberra, Australia. [online] URL: http://passthrough. fw-notify.net/download/801603/http://caepr.anu.edu.au/sites/default/ files/Publications/DP/1993 DP48.pdf.
Dambacher, J. M., D. T. Brewer, D. M. Dennis, M. Macintyre, and S. Foale. 2007. Qualitative modelling of gold mine impacts on Lihir Island's socioeconomic system and reef-edge fish community. Environmental Science and Technology 41(2):555-562. http://dx.doi.org/10.1021/es0610333

Dambacher, J. M., H. W. Li, and P. A. Rossignol. 2002. Relevance of community structure in assessing indeterminacy of ecological predictions. Ecology 83(5):1372-1385. http://dx.doi.org/10.1890/0012-9658 (2002)083[1372:ROCSIA]2.0.CO;2

Dambacher, J. M., H. W. Li, and P. A. Rossignol. $2003 a$. Qualitative predictions in model ecosystems. Ecological Modelling 161(1-2):79-93. http://dx.doi.org/10.1016/S0304-3800 (02)00295-8

Dambacher, J. M., H.-K. Luh, H. W. Li, and P. A. Rossignol. 2003b. Qualitative stability and ambiguity in model ecosystems. American Naturalist 161(6):876-888. http://dx.doi.org/10.1086/367590

Dambacher, J. M., and R. Ramos-Jiliberto. 2007. Understanding and predicting effects of modified interactions through a qualitative analysis of community structure. Quarterly Review of Biology 82(3):227-250. http://dx.doi.org/10.1086/519966

de Heer, R., and P. Djigirr, directors. 2006. Ten canoes. [Feature film]. Palace Films, Sydney, Australia.

Di Baldassarre, G., M. Kooy, J. S. Kemerink, and L. Brandimarte. 2013. Towards understanding the dynamic behaviour of floodplains as human-water systems. Hydrological and Earth System Sciences 17:3235-3244. http://dx.doi.org/10.5194/

hess-17-3235-2013

Dockery, A. M. 2010. Culture and wellbeing: the case of indigenous Australians. Social Indicators Research 99(2):315-332. http://dx.doi.org/10.1007/s11205-010-9582-y

Douglas, M. M., S. E. Bunn, and P. M. Davies. 2005. River and wetland food webs in Australia's wet-dry tropics: general principles and implications for management. Marine and Freshwater Research 56(3):329-342. http://dx.doi.org/10.1071/ $\underline{\mathrm{MF} 04084}$

Ens, E., and T. McDonald. 2012. Caring for country: Australian natural and cultural resource management. Ecological Management and Restoration 13(1):1. http://dx.doi.org/10.1111/ j.1442-8903.2011.00633.X

Ertsen, M. W., J. T. Murphy, L. E. Purdue, and T. Zhu. 2014. A journey of a thousand miles begins with one small step - human agency, hydrological processes and time in socio-hydrology. Hydrological and Earth System Sciences 18:1369-1382. http://dx. doi.org/10.5194/hess-18-1369-2014

Ferguson, H. 2011. Inuit food (in)security in Canada: assessing the implications and effectiveness of policy. Queen's Policy Review 2(2):54-79. [online] URL: http://www.queensu.ca/sps/qpr/issues/ vol2issue $2 /$ Ferguson.pdf.

Finn, M., and S. Jackson. 2011. Protecting indigenous values in water management: a challenge to conventional environmental flow assessments. Ecosystems 14(8):1232-1248. http://dx.doi. org/10.1007/s10021-011-9476-0 
Fogarty, W. 2005. 'You got any truck?': vehicles and decentralised mobile service-provision in remote Indigenous Australia. CAEPR Working Paper 30/2005. CAEPR, Canberra, Australia. [online] URL: http://caepr.anu.edu.au/sites/default/files/Publications/WP/ CAEPRWP30.pdf.

Gammage, B. 2011. The biggest estate on earth: how Aborigines made Australia. Allen and Unwin, Melbourne, Australia.

Garnett, S. T., B. Sithole, P. J. Whitehead, C. P. Burgess, F. H. Johnston, and T. Lea. 2009. Healthy country, healthy people: policy implications of links between indigenous human health and environmental condition in tropical Australia. Australian Journal of Public Administration 68(1):53-66. http://dx.doi. org/10.1111/j.1467-8500.2008.00609.x

Gilmour, P. W., P. D. Dwyer, and R. W. Day. 2013. Enhancing the agency of fishers: a conceptual model of self-management in Australian abalone fisheries. Marine Policy 37:165-175. http://dx. doi.org/10.1016/j.marpol.2012.04.015

Gombay, N. 2014. 'Poaching' - What's in a name? Debates about law, property, and protection in the context of settler colonialism. Geoforum 55:1-12. http://dx.doi.org/10.1016/j.geoforum.2014.04.010

Gorman, J. T., P. J. Whitehead, A. D. Griffiths, and L. Petheram. 2008. Production from marginal lands: indigenous commercial use of wild animals in northern Australia. International Journal of Sustainable Development and World Ecology 15(3):240-250. http://dx.doi.org/10.3843/SusDev.15.3:7

Gould, R. 1982. To have and have not: the ecology of sharing among hunter-gatherers. Pages 69-91 in N. M. Williams and E. S. Hunn, editors. Resource managers: North American and Australian hunter-gatherers. Westview Press, Boulder, Colorado, USA.

Hale, D., G. Lady, J. Maybee, and J. Quirk. 1999. Nonparametric comparative statics and stability. Princeton University Press, Princeton, New Jersey, USA.

Hare, M. 2011. Forms of participatory modelling and its potential for widespread adoption in the water sector. Environmental Policy and Governance 21(6):386-402. http://dx.doi.org/10.1002/eet.590

Henry, G. W., and J. M. Lyle, editors. 2003. The national recreational and indigenous fishing survey. FRDC Project 99/158. Commonwealth of Australia, Canberra, Australia. [online] ULR: http://passthrough.fw-notify.net/download/981441/http://www. environment.gov.au/system/files/pages/5886ef12-7b4a-40fd-aea5c08e7621ecbf/files/co62nationalrecreationalfishingsurvey.pdf.

Hill, R., P. L. Pert, J. Davies, C. J. Robinson, F. Walsh, and F. Falco-Mammone. 2013. Indigenous landmanagement in Australia: extent, scope, diversity, barriers and success factors. CSIRO Ecosystem Sciences, Cairns, Australia.

Holmes, J. 2010. The multifunctional transition in Australia's tropical savannas: the emergence of consumption, protection and indigenous values. Geographical Research 48(3):265-280. http:// dx.doi.org/10.1111/j.1745-5871.2009.00629.X

Horstman, M., and G. Wightman. 2001. Karparti ecology: recognition of Aboriginal ecological knowledge and its application to management in north-western Australia. Ecological Management and Restoration 2(2):99-109.
Hosack, G. R., K. R. Hayes, and J. M. Dambacher. 2008. Assessing model structure uncertainty through an analysis of system feedback and Bayesian networks. Ecological Applications 18(4):1070-1082. http://dx.doi.org/10.1890/07-0482.1

Ingold, T. 2000. The perception of the environment: essays on livelihood, dwelling and skill. Routledge, London, UK. http://dx. doi.org/10.4324/9780203466025

Ingold, T., D. Riches, and J. Woodburn, editors. 1988. Hunters and gatherers: volume 2: property, power and ideology. Berg, Oxford, UK.

Jackson, S. 2011. Aboriginal access to water in Australia: opportunities and constraints. Pages 601-628 in R. Q. Grafton and K. Hussey, editors. Water resources, planning and management. Cambridge University Press, Cambridge, UK. http://dx.doi.org/10.1017/CBO9780511974304.031

Jackson, S., and J. Altman. 2009. Indigenous rights and water policy: perspectives from tropical northern Australia. Australian Indigenous Law Review 13(1):27-48.

Jackson, S., and M. Barber. 2013. Recognition of indigenous water values in Australia's Northern Territory: current progress and ongoing challenges for social justice in water planning. Planning Theory and Practice 14(4):435-454. http://dx.doi. org/10.1080/14649357.2013.845684

Jackson, S., M. Finn, and P. Featherston. 2012a. Aquatic resource use by indigenous Australians in two tropical river catchments: the Fitzroy River and Daly River. Human Ecology 40(6):893-908. http://dx.doi.org/10.1007/s10745-012-9518-z

Jackson, S., M. Finn, and K. Scheepers. 2014. The use of replacement cost method to assess and manage the impacts of water resource development on Australian indigenous customary economies. Journal of Environmental Management 135:100-109. http://dx.doi.org/10.1016/j.jenvman.2014.01.018

Jackson, S., M. Finn, E. Woodward, and P. Featherston. 2011. Indigenous socio-economic values and river flows. CSIRO and TRaCK, Darwin, Australia.

Jackson, S., P.-L. Tan, C. Mooney, S. Hoverman, and I. White. 2012b. Principles and guidelines for good practice in Indigenous engagement in water planning. Journal of Hydrology 474:57-65. http://dx.doi.org/10.1016/j.jhydrol.2011.12.015

Jardine, T. D., N. E. Pettit, D. M. Warfe, B. J. Pusey, D. P. Ward, M. M. Douglas, P. M. Davies, and S. E. Bunn. 2012. Consumerresource coupling in wet-dry tropical rivers. Journal of Animal Ecology 81(2):310-322. http://dx.doi.org/10.1111/j.1365-2656.2011.01925. $\underline{\mathrm{x}}$

Johnston, F. H., S. P. Jacups, A. J. Vickery, and D. M. J. S. Bowman. 2007. Ecohealth and Aboriginal testimony of the nexus between human health and place. EcoHealth 4(4):489-499. http://dx.doi. org/10.1007/s10393-007-0142-0

Keen, I. 1994. Knowledge and secrecy in an Aboriginal religion. Oxford University Press, Oxford, UK.

Keen, I. 2004. Aboriginal economy and society: Australia at the threshold of colonisation. Oxford University Press, Melbourne, Australia. 
Kuipers, B. 1994. Qualitative reasoning: modeling and simulation with incomplete knowledge. MIT Press, Cambridge, Massachusetts, USA.

Laudine, C. 2009. Aboriginal environmental knowledge: rational reverence. Ashgate, Farnham, UK.

Levins, R. 1974. The qualitative analysis of partially specified systems. Annals of the New York Academy of Sciences 231:123-138. http://dx.doi.org/10.1111/j.1749-6632.1974.tb20562. $\underline{\mathrm{x}}$

Levins, R. 1998. Qualitative mathematics for understanding, prediction, and intervention in complex ecosystems. Pages 178-204 in D. Rapport, R. Constanza, P. Epstein, C. Gaudet, and R. Levins, editors. Ecosystem health: principles and practices. Blackwell, Malden, Massachusetts, USA.

Liedloff, A. C., E. L. Woodward, G. A. Harrington, and S. Jackson. 2013. Integrating indigenous ecological and scientific hydro-geological knowledge using a Bayesian Network in the context of water resource development. Journal of Hydrology 499:177-187. http://dx.doi.org/10.1016/j.jhydrol.2013.06.051

Long, S., and P. Memmott. 2007. Aboriginal mobility and the sustainability of communities: case studies from north-west Queensland and eastern Northern Territory. Working Paper 5. Desert Knowledge CRC, Alice Springs, Australia. [online] URL: http://citeseerx.ist.psu.edu/viewdoc/download?doi=10.1.1.156.6529\&rep= rep1\&type $=$ pdf.

Loos, N. 2007. White Christ, black cross: the emergence of a black church. Aboriginal Studies Press, Canberra, Australia.

Maclean, K., R. Bark, B. Moggridge, S. Jackson, and C. Pollino. 2012. Ngemba water values and interests: Ngemba Old Mission Billabong and Brewarrina Aboriginal fish traps (Baiame's Nguunhu). CSIRO, Brisbane, Australia. [online] URL: https:// publications.csiro.au/rpr/pub? pid=csiro:EP127320.

Magowan, F. 2007. Globalisation and indigenous Christianity: translocal sentiments in Australian Aboriginal Christian songs. Identities: Global Studies in Culture and Power 14(4):459-483. http://dx.doi.org/10.1080/10702890701578472

Marzloff, M. P., J. M. Dambacher, C. R. Johnson, L. R. Little, and S. D. Frusher. 2011. Exploring alternative states in ecological systems with a qualitative analysis of community feedback. Ecological Modelling 222(15):2651-2662. http://dx.doi.org/10.1016/ j.ecolmodel.2011.03.040

McCarthy, F., and M. McArthur. 1960. The food quest and the time factor in Aboriginal economic life. Pages 145-180 in C. P. Mountford, editor. Records of the American-Australian scientific expedition to Arnhem Land, volume 2: anthropology and nutrition. Melbourne Univeristy Press, Melbourne, Australia.

McGregor, S., V. Lawson, P. Christophersen, R. Kennett, J. Boyden, P. Bayliss, A. Liedloff, B. McKaige, and A. N. Andersen. 2010. Indigenous wetland burning: conserving natural and cultural resources in Australia's World Heritage-listed Kakadu National Park. Human Ecology 38(6):721-729. http://dx.doi. org/10.1007/s10745-010-9362-y

Meehan, B. 1982. Shell bed to shell midden. Australian Institute Of Aboriginal Studies, Canberra, Australia.
Merlan, F. 1982. A Mangarrayi representational system: environment and cultural symbolization in northern Australia. American Ethnologist 9(1):145-166. http://dx.doi.org/10.1525/ ae.1982.9.1.02a00090

Merlan, F. 1987. Catfish and alligator: totemic songs of the western Roper River, Northern Territory. Pages 142-167 in M. Clunies-Ross, T. Donaldson, and S. Wild, editors. Songs of Aboriginal Australia. University of Sydney, Sydney, Australia.

Miller, J., K. James, and P. Maggiore. 1993. Tables of composition of Australian Aboriginal foods. Aboriginal Studies Press, Canberra, Australia.

Morphy, F., and H. Morphy. 2012. Soon we will be spending all our time at funerals: Yolngu mortuary rituals in an epoch of constant change. Pages 49-72 in S. Howell and A. Talle, editors. Returns to the field: multitemporal research and contemporary anthropology. Indiana University Press, Bloomington, Indiana, USA.

Morphy, H. 1984. Journey to the crocodile's nest: an accompanying monograph to the film 'Madarrpa Funeral at Gurka'wuy'. Australian Institute Of Aboriginal Studies, Canberra, Australia.

Morphy, H. 1995. Landscape and the reproduction of the ancestral past. Pages 184-209 in E. Hirsch and M. O'Hanlon, editors. The anthropology of landscape. Oxford University Press, Oxford, UK.

Morphy, H. 2004. An anthropological report on the Yolngu people of Blue Mud Bay, in relation to their claim to Native Title in the land and sea. Report prepared at the instruction of the Northern Land Council, Centre for Cross-Cultural Research, Australian National University, Canberra, Australia.

Morphy, H., and F. Morphy. 2006. Tasting the waters: discriminating identities in the waters of Blue Mud Bay. Journal of Material Culture 11(1-2):67-85. http://dx.doi.org/10.1177/135$\underline{9183506063012}$

Morrison, J. 2007. Caring for country. Pages 249-261 in J. Altman and M. Hinkson, editors. Coercive reconciliation: stabilise, normalise, exit Aboriginal Australia. Arena Publications Association, Melbourne, Australia.

O'Dea, K., P. A. Jewell, A. Whiten, S. A. Altmann, S. S. Strickland, and O. T. Oftedal. 1991. Traditional diet and food preferences of Australian Aboriginal hunter-gatherers [and discussion]. Philosophical Transactions of the Royal Society B 334:233-241. http://dx.doi.org/10.1098/rstb.1991.0112

Parry, L., J. Barlow, and C. A. Peres. 2009. Hunting for sustainability in tropical secondary forests. Conservation Biology 23(5):1270-1280. http://dx.doi.org/10.1111/j.1523-1739.2009.01224. $\underline{\mathrm{X}}$

Peterson, N. 1993. Demand sharing: reciprocity and the pressure for generosity among foragers. American Anthropologist 95 (4):860-874. http://dx.doi.org/10.1525/aa.1993.95.4.02a00050

Peterson, N. 2013. On the persistence of sharing: personhood, asymmetrical reciprocity, and demand sharing in the Indigenous Australian domestic moral economy. Australian Journal of Anthropology 24(2):166-176. http://dx.doi.org/10.1111/taja.12036 
Phelan, M. 2003. Sciaenid aggregations in northern Australia: an example of successful outcomes through collaborative research. Pages 100-109 in N. Haggan, C. Brignall, and L. Wood, editors. Putting fishers' knowledge to work: conference proceedings. Fisheries Centre Research Reports Volume 11 Number 1. Fisheries Centre, University of British Columbia, Vancouver, Canada.

Povinelli, E. A. 1992. "Where we gana go now": foraging practices and their meanings among the Belyuen Australian Aborigines. Human Ecology 20(2):169-202. http://dx.doi.org/10.1007/ $\underline{\mathrm{BF} 00889078}$

Prober, S. M., M. H. O'Connor, and F. J. Walsh. 2011. Australian Aboriginal peoples' seasonal knowledge: a potential basis for shared understanding in environmental management. Ecology and Society 16(2): 12. [online] URL: http://www.ecologyandsociety. org/vol16/iss2/art12/.

Puccia, C., and R. Levins. 1985. Qualitative modeling of complex systems: an introduction to loop analysis and time averaging. Harvard University Press, Cambridge, Massachusetts, USA. http://dx.doi.org/10.4159/harvard.9780674435070

Purdie, N., P. Dudgeon, and R. Walker, editors. 2010. Working together: Aboriginal and Torres Strait Islander mental health and wellbeing principles and practice. Department of Health and Ageing, Commonwealth of Australia, Canberra, Australia. [online] URL: http://aboriginal.telethonkids.org.au/media/54847/ working together_full_book.pdf.

Pusey, B., editor. 2011a. Aquatic biodiversity in northern Australia: patterns, threats and future. Charles Darwin University Press, Darwin, Australia.

Pusey, B., editor. 2011b. Northern waters: aquatic biodiversity of the Australian wet-dry tropics. Charles Darwin University Press, Darwin, Australia.

Putnis, A., P. Josif, and E. Woodward. 2007. Healthy country, healthy people: supporting Indigenous engagement in the sustainable management of Northern Territory land and seas. CSIRO, Darwin, Australia. [online] URL: $\underline{\text { htp: } / / \text { www.csiro.au/ / }}$ media/CSIROau/Divisions/CSIRO $\% 20$ Sustainable $\% 20$ Ecosystems/ healthyCountryPeople CSE pdf\%20Standard.pdf.

Quirk, J., and R. Ruppert. 1965. Qualitative economics and the stability of equilibrium. Review of Economic Studies 32 (4):311-326. http://dx.doi.org/10.2307/2295838

Rae, C. J., V. J. Lamprell, R. J. Lion, and A. M. Rae. 1982. The role of bush foods in contemporary Aboriginal diets. Proceedings of the Nutrition Society of Australia 7:45-49. [online] URL: http:// apjen.nhri.org.tw/server/APJCN/ProcNutSoc/1980-1989/1982/1982\% 20p045-049.pdf.

Reid, J., and P. Trompf, editors. 1991. The health of aboriginal Australia. Harcourt Brace Jovanovich, Marrickville, Australia.

Rist, J., M. Rowcliffe, G. Cowlishaw, and E. J. Milner-Gulland. 2008. Evaluating measures of hunting effort in a bushmeat system. Biological Conservation 141(8):2086-2099. http://dx.doi. org/10.1016/j.biocon.2008.06.005

Roberts, F. S. 1971. Signed digraphs and the growing demand for energy. Environment and Planning 3(4):395-410. http://dx.doi. org/10.1068/a030395
Roberts, J. G., S. Y. Conway, R. Morgan, A. Dirngayg, S. Harris, E. B. Farrar, F. B. Roberts, F. Merlan, E. Collyer, T. Calnan, and G. Wightman. 2011. Mangarrayi and Yangman plants and animals: Aboriginal biocultural knowledge from Elsey and the Roper River, north Australia. Diwurruwurru-jaru Aboriginal Corp/Mimi Aboriginal Art and Craft, Department of Natural Resources, Environment, the Arts and Sport, and the Indigenous Literacy Foundation, Katherine, Australia.

Rose, D. B., editor. 1995. Country in flames: proceedings of the 1994 Symposium on Biodiversity and Fire in North Australia. Biodiversity Unit, Department of the Environment, Sport and Territories and North Australia Research Unit, Australian National University, Canberra, Australia.

Rose, D. B. 1996. Nourishing terrains: Australian Aboriginal views of landscape and wilderness. Australian Heritage Commission, Canberra, Australia. [online] URL: http://www.environment.gov. au/system/files/resources/62db1069-b7ec-4d63-b9a9-991f4b931a60/ files/nourishing-terrains.pdf.

Rose, D. B. 2000. Dingo makes us human: life and land in an Australian Aboriginal culture. Cambridge University Press, Cambridge, UK.

Rouja, P. M., É. Dewailly, C. Blanchet, and the Bardi Community. 2003. Fat, fishing patterns, and health among the Bardi people of North Western Australia. Lipids 38(4):399-405. http://dx.doi. org/10.1007/s11745-003-1075-Z

Rowcliffe, J. M., E. J. Milner-Gulland, and G. Cowlishaw. 2005. Do bushmeat consumers have other fish to fry? Trends in Ecology and Evolution 20(6):274-276. http://dx.doi.org/10.1016/j.tree.2005.03.007

Russell-Smith, J., D. Lucas, M. Gapindi, B. Gunbunuka, N. Kapirigi, G. Namingum, K. Lucas, P. Giuliani, and G. Chaloupka. 1997. Aboriginal resource utilization and fire management practice in western Arnhem Land, monsoonal northern Australia: notes for prehistory, lessons for the future. Human Ecology 25(2):159-195. http://dx.doi.org/10.1023/ A:1021970021670

Saethre, E. 2005. Nutrition, economics and food distribution in an Australian Aboriginal community. Anthropological Forum 15 (2):151-169. http://dx.doi.org/10.1080/00664670500135212

Saethre, E. 2011. Demand sharing, nutrition, and Warlpiri health: the social and economic strategies of food choice. Pages 175-186 in Y. Musharbash and M. Barber, editors. Ethnography and the production of anthropological knowledge: essays in honour of Nicolas Peterson. ANU ePress, Canberra, Australia.

Salles, P., and B. Bredeweg. 2006. Modelling population and community dynamics with qualitative reasoning. Ecological Modelling 195(1-2):114-128. http://dx.doi.org/10.1016/j. ecolmodel.2005.11.014

Samuelson, P. A. 1947. Foundations of economic analysis. Harvard University Press, Cambridge, Massachusetts, USA.

Scelza, B. A., D. W. Bird, and R. Bliege Bird. 2014. Bush tucker, shop tucker: production, consumption, and diet at an Aboriginal outstation. Ecology of Food and Nutrition 53(1):98-117. http://dx. doi.org/10.1080/03670244.2013.772513 
Scheepers, K., and S. Jackson. 2012. Indigenous people's socioeconomic values and river flows in the Mitchell River delta, Cape York. CSIRO, Darwin, Australia. [online] URL: https:// publications. csiro. au/rpr/download? pid=csiro:EP127687\&dsid=DS6.

Smith, P. A., and R. M. Smith. 1999. Diets in transition: huntergatherer to station diet and station diet to the self-select store diet. Human Ecology 27(1):115-133. http://dx.doi.org/10.1023/ $\underline{\text { A:1018709401639 }}$

Stacey, N., A. Izurieta, and S. T. Garnett. 2013. Collaborative measurement of performance of jointly managed protected areas in northern Australia. Ecology and Society 18(1): 19. http://dx. doi.org/10.5751/ES-05273-180119

Stoeckl, N., S. Jackson, F. Pantus, M. Finn, M. J. Kennard, and B. J. Pusey. 2013. An integrated assessment of financial, hydrological, ecological and social impacts of 'development' on Indigenous and non-Indigenous people in northern Australia. Biological Conservation 159:214-221. http://dx.doi.org/10.1016/j. biocon.2012.12.007

Strang, V. 1997. Uncommon ground: cultural landscapes and environmental values. Berg, Oxford, UK.

Strang, V. 2001. Negotiating the river: cultural tributaries in far north Queensland. Pages 69-86 in B. Bender and M. Winer, editors. Contested landscapes: movement, exile, place. Berg, Oxford, UK.

Strang, V. 2005. Water works: agency and creativity in the Mitchell River catchment. Australian Journal of Anthropology 16 (3):366-381. http://dx.doi.org/10.1111/j.1835-9310.2005.tb00317. $\underline{\mathrm{X}}$

Sullivan, P. 1998. Salt water, fresh water, and Yawuru social organisation. Pages 96-108 in N. Peterson and B. Rigsby, editors. Customary marine tenure in Australia. Oceania, Sydney, Australia.

Thomson, D. 1949. Economic structure and the ceremonial exchange cycle in Arnhem Land. Macmillan, Melbourne, Australia.

Tidwell, V. C., H. D. Passell, S. H. Conrad, and R. P. Thomas. 2004. System dynamics modeling for community-based water planning: application to the middle Rio Grande. Aquatic Sciences 66(4):357-372. http://dx.doi.org/10.1007/s00027-004-0722-9

Toussaint, S. 2014. Fishing for fish and for Jaminyjarti in northern Aboriginal Australia. Oceania 84(1):38-51. http://dx.doi. org/10.1002/ocea.5034

Toussaint, S., P. Sullivan, and S. Yu. 2005. Water ways in Aboriginal Australia: an interconnected analysis. Anthropological Forum 15(1):61-74. http://dx.doi.org/10.1080/0066467042000336715

Ulijaszek, S. J. 2001. Potential seasonal ecological challenge of heat strain among Australian Aboriginal people practicing traditional subsistence methods: a computer simulation. American Journal of Physical Anthropology 116(3):236-245. http://dx.doi.org/10.1002/ajpa.1119

van Putten, I., A. Lalancette, P. Bayliss, D. Dennis, T. Hutton, A. Norman-López, S. Pascoe, E. Plagányi, and T. Skewes. 2013. A Bayesian model of factors influencing indigenous participation in the Torres Strait tropical rocklobster fishery. Marine Policy 37:96-105. http://dx.doi.org/10.1016/j.marpol.2012.04.001

Walker, J. 2010. Processes for effective management: learning from agencies and Warlpiri people involved in managing the Northern Tanami Indigenous Protected Area, Australia. Dissertation. Charles Darwin University, Darwin, Australia. [online] URL: http://espace.cdu.edu.au/eserv/cdu:13192/Thesis_CDU_13192_Walker_J. pdf.

Walsh, F. 2008. To hunt and to hold: Martu Aboriginal people's uses and knowledge of their country, with implications for comanagement in Karlamilyi (Rudall River) National Park and the Great Sandy Desert, Western Australia. Dissertation. University of Western Australia, Perth, Australia.

Wheeler, P., and T. Thornton. 2005. Subsistence research in Alaska: a thirty year retrospective. Alaskan Journal of Anthropology 3(1):69-104.

Williams, N. 1986. The Yolngu and their land: a system of land tenure and the fight for its recognition. Australian Institute Of Aboriginal Studies, Canberra, Australia.

Williams, N., and E. Hunn, editors. 1982. Resource managers: North American and Australian hunter-gatherers. Westview Press, Boulder, Colorado, USA.

Woodward, E., S. Jackson, M. Finn, and P. Marfurra McTaggart. 2012. Utilising Indigenous seasonal knowledge to understand indigenous aquatic resource use and inform water resource management in northern Australia. Ecological Management and Restoration 13(1):58-64. http://dx.doi.org/10.1111/j.1442-8903.2011.00622. $\underline{x}$

Yingguny Lindsay, B., K. Waliwararra, and F. Miljat. 2001. Malakmalak and Matngala plants and animals: Aboriginal flora and fauna knowledge from the Daly River area, Northern Australia. Parks and Wildlife Commission of the Northern Territory, Darwin, Australia.

Zubrick, S., P. Dudgeon, G. Gee, B. Glaskin, K. Kelly, Y. Paradies, C. Scrine, and R. Walker. 2004. Social determinants of Aboriginal and Torres Strait Islander social and emotional wellbeing. Page 75 in N. Purdie, P. Dudgeon, and R. Walker, editors. Working together: Aboriginal and Torres Strait Islander mental health and wellbeing principles and practice. Commonwealth of Australia, Canberra, Australia. 